TOMASZ JASIŃSKI

UNIWERSYTET MARII CURIE-SKŁODOWSKIEJ W LUBLINIE

\title{
BEZTEKSTOWY PRZEKAZ ANONIMOWEGO \\ PSALMU DAWIDA W TABULATURZE ORGANOWEJ Z KROŻ. REKONSTRUKCJA WARSTWY SŁOWNEJ I PRÓBA ATRYBUCJI
}

\begin{abstract}
Siedemnastowieczna rękopiśmienna tabulatura organowa z litewskich Kroż, opublikowana w postaci faksymilowej w $2017 \mathrm{r}^{\mathrm{I}}$, kryje w sobie wiele nierozwiązanych zagadek wynikających przede wszystkim z obecności licznych kompozycji anonimowych. Jedną z nich - trzygłosową pieśń Stuchaj, co żywo - poddałem transkrypcji i opisałem ostatnio na łamach Muzyki, próbując jednocześnie ostrożnie zasugerować atrybucję, która wskazywałaby na Adama z Wagrowca jako potencjalnego kompozytora tego utworu ${ }^{2}$. Niemal równolegle zainteresowanie moje wzbudziła również inna pozycja żmudzkiego zabytku - anonimowy Psalm Dawida ${ }^{3}$. Utwór ten, podobnie jak wspomnianą pieśń, warto opublikować w transkrypcji, bliżej opisać i podjąć narzucający się tu problem atrybucji.
\end{abstract}

Psalm Dawida to kompozycja czterogłosowa o dyspozycji a voce piena, dość rozbudowana, zapisana notacją wokalną w formie partytury, pozbawiona jednak tekstu słownego, choćby nawet jego incipitu. Figurujący ponad partyturą polskojęzyczny tytuł utworu sugeruje, iż mamy przed sobą dzieło z tekstem w języku polskim, choć nie przesądza o tym. Dopiero znak repetycji w t. I9, nakazujący powtórzenie wstępnego odcinka utworu (t. I-I9), dowodzi, że chodzi tu o tekst wierszowany, który umożliwia powtórzenie wersu/strofy z tym samym opracowaniem muzycznym. Bez wątpienia musiał to być tekst poetycki w języku polskim. Pojawia się pytanie: który

1 Liber Organistarum Collegii Crosensis Societatis Jesu, wyd. Laima Budzinauskienè, Rasa Murauskaite, Warszawa 2017 (= Fontes Musicae in Polonia B/II).

2 Tomasz Jasiński, „Rekonstrukcja warstwy słownej pieśni Stuchaj, co żywo zapisanej w tabulaturze organowej z Kroż", Muzyka 66 (2021) nr 1, s. 169-179.

3 Zob. Liber Organistarum, s. 93-99. 
to psalm? Cenną podpowiedź przynosi znak naniesiony (być może dopisany ex post) między oboma słowami tytułu, wyglądający na dolną końcówkę cyfry I (ewentualnie cyfry 4 lub 7), co skłoniło mnie do tego, aby w pierwszym rzędzie przyjrzeć się polskim przekładom pierwszego psalmu Dawidowego Beatus vir qui non abiit.

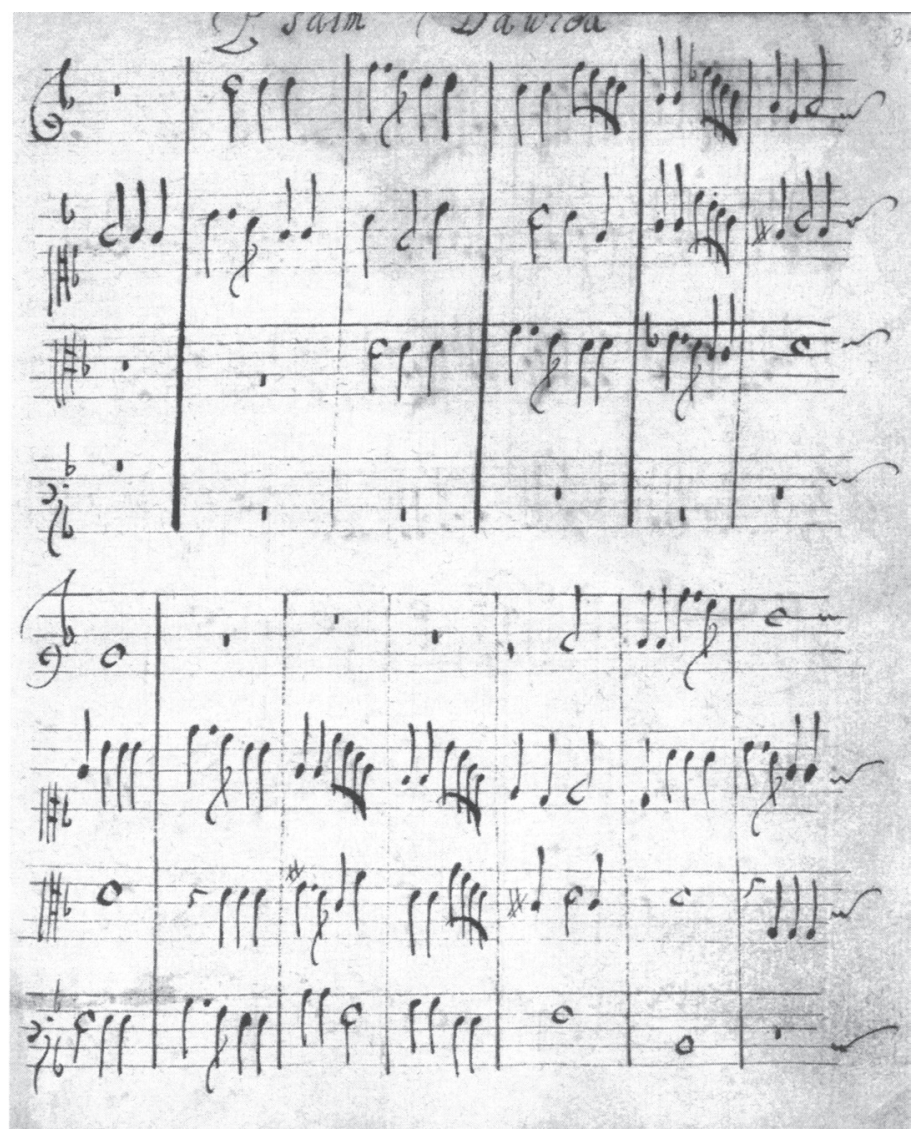

Il. I. Psalm Dawida (początkowy fragment), facsimile z Tabulatury z Kro $\dot{z}^{4}$

Dokonałem licznych symulacji uzgodnienia słów tego psalmu z zapisem nutowym, sięgając po wszystkie znane mi staropolskie przekłady poetyckie, m.in. Jana Kochanowskiego (Szczęśliwy, który nie byt miedzy ztemi w radzie), Jakuba Lubelczyka (Btogostawiony to cztowiek, który w to ugodzi), Macieja Rybińskiego (Ten, co nie winien bezbożnych rady), Andrzeja Trzecieskiego (Btogostawiony cztowiek, co sie tak sprawuje), a także autorów anonimowych. Próby te doprowadziły mnie do przekonania, że może w tym wypadku chodzić o wiersz Trzecieskiego albo Kochanowskiego. Oba 
teksty to trzynastozgłoskowce z identycznie usytuowaną średniówką po siódmej sylabie, korespondujące $\mathrm{z}$ formalno-rytmiczną strukturą kompozycji. Jednocześnie, wertując kancjonały staropolskie, natrafiłem w Cantionale Piotra Artomiusza z I640 r. na melodię psalmu Btogostawiony cztowiek, co sie tak sprawuje ze słowami Andrzeja Trzecieskiego (pieśń nr CCXXXV), która - i nie ma tu żadnych wątpliwości - posłużyła twórcy Psalmu Dawida za soggetto della cantilenas. Równocześnie w Przydatku Psalmów Dawidowych tegoż kancjonału widnieje przekład Jana Kochanowskiego Szczęśliwy, który nie byt miedzy ztemi w radzie (pieśń nr CCCXXXIV), z adnotacją: „Na tę Notę: Błogosławiony człowiek, co się tak. CCXXXV”. Wiemy stąd, że melodia podana przez Artomiusza funkcjonowała i z jednym, i z drugim tekstem (zob. przykł. I). Który z nich zatem stał się treścią Psalmu?

Przykł. I. Melodia psalmu nr I z kancjonału Piotra Artomiusza z podpisanymi słowami Andrzeja Trzecieskiego (według źródła) i Jana Kochanowskiego
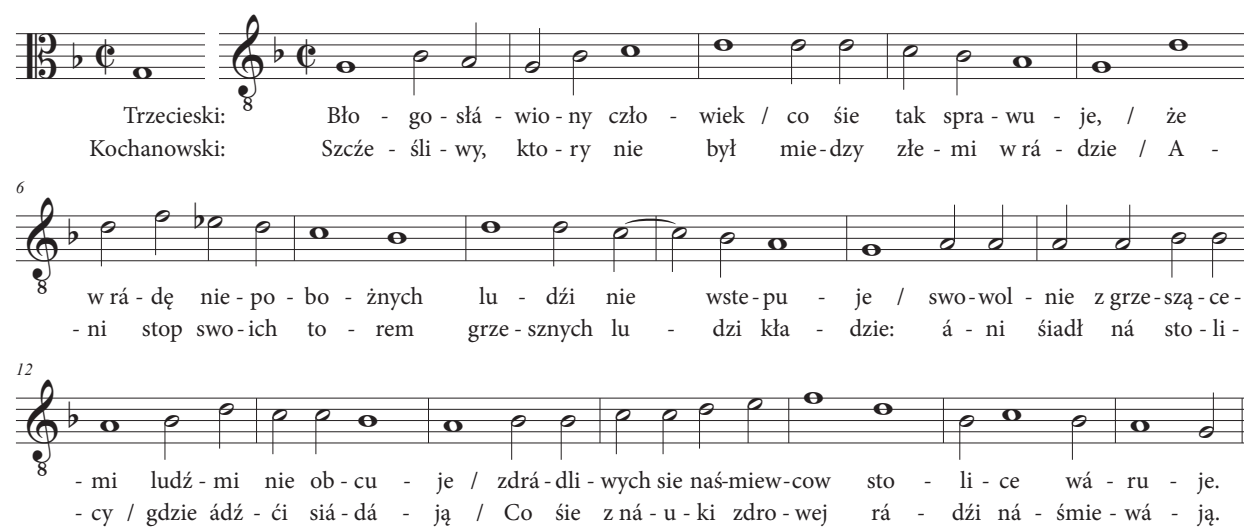

Rozwiązanie tej kwestii wymaga spojrzenia analitycznego odwołującego się zarówno do przekazu źródłowego dzieła (zob. il. I) oraz przedstawionego przykładu nutowego (zob. przykł. I), jak i do transkrypcji Psalmu Dawida, która zostanie zaprezentowana dopiero w późniejszej partii tekstu (zob. przykł. 2).

Najpierw trzeba zauważyć, że niezależnie od tego, który przekład stał się warstwą słowną Psalmu, opracowaniu muzycznemu mogły posłużyć najwyżej dwie strofy

5 Piotr Artomiusz, Cantional, To jest Pieśni krześciańskie ku Chwale Boga w Troycy jedynego y pociesze Wiernych jego porzadkiem nie tylko stusznym, ale też z pilnościq wielka, nad pierwsze wydania, nie bez Correctury znaczney wypuszczone; z Przydatkiem Psalmów y Piosneczek teraz nowo zebranych, Gdańsk 1640 Andrzej Hünefeld, rozdział Psalmy Dawidowe które częściq wedtug Not częścią Choratem śpiewać możesz [nr pieśni] CCXXXV. Psalmus I., folio R.

6 Ibid., rozdział Przydatek Psalmów Dawidowych niektórych Przektadania Jana Kochanowskiego y Pieśni kilka, [numer pieśni] CCCXXXIV. Psal. I. Na tę Notę: Błogosławiony człowiek, co się tak. CCXXXV., folio Ji. 
wiersza, co bezpośrednio unaocznia konstrukcja całej kompozycji muzycznej. Oto dwie pierwsze strofy autorstwa Trzecieskiego:

Błogosłáwiony cźłowiek / co śie tak spráwuje /

że w rádę niepobożnych ludźi nie wstepuje /

swowolnie z grzeszącemi ludźmi nie obcuje /

zdrádliwych śie naśmiewców stolice wáruje.

Ale w Zakonie Pánskim ma swoje kochánie /

á w nim we dnie y w nocy pilne rozmyślánie /

ten będźie jako drzewo przy wodách szczepione /

á z buynośći szeroce wielkiey rozkrzewione7.

To natomiast paralelny fragment z Kochanowskiego:

Szcźeśliwy / ktory nie był miedzy złemi w rádzie /

Ani stop swoich torem grzesznych ludzi kładźie:

áni śiadł ná stolicy / gdzie ádźci śiádáją /

Co śie z náuki zdrowey rádźi náśmiewáją.

Ale to jego umysł, to jego stáránie /

Aby ná wszytkim pełnił Panskie przykazánie:

Dzieńli po niebie wiedzie / nocli swoje konie /

On ostáwicźnie w Panskim rozmyśla zakonie ${ }^{8}$.

Podstawowa rzecz do ustalenia jest następująca: czy odcinek podlegający repetycji (t. I-I9) obejmuje tylko pierwszy wers strofy, czy też dwa jej pierwsze wersy9? Przy pierwszym wariancie wstępny odcinek kompozycji (licząc repetycję) ujmowałby połowę strofy; w drugim natomiast wypadku mieściłby w sobie całą strofę, co jednak śmiało możemy wykluczyć, ponieważ w obu przekładach pierwsze słowa drugiej strofy („Ale

7 Cyt. za: ibid., folio R.

8 Cyt. za: ibid., folio Ji.

9 Należy w tym miejscu zatrzymać się przy konstrukcji pierwszego odcinka utworu (zob. przykł. 2, t. 1-19). Stanowi on imitacyjne przeprowadzenie jednej frazy tematycznej. W praktyce kompozytorskiej na gruncie dzieł przeimitowanych zwykle jedna fraza tematyczna wiązała się z prezentacją jednego i tego samego segmentu tekstu słownego (jakkolwiek odstępstwa od tego też są znane) - i to właśnie w pierwszym rzędzie przemawia za tym, że cały odcinek jest prezentacją wstępnego wersu strofy. Możliwości jednak, że fraza tematyczna pierwszego odcinka mogłaby wiązać się od t. 12 z drugim wersem zwrotki, sprzyja okoliczność, iż w materiale prekompozycyjnym (por. przykł. 1) linia melodyczna związana z początkiem drugiego wersu zaczyna się niemal tym samym wzorem melicznym (t. 5-6: $d^{1}-f^{1}-e s^{1}-d^{1}$ ) co odcinek inicjalny (t. 1-2: $g-b-a-g$ ), a to mogłoby się stać źródłem pomysłu kompozytorskiego, aby cały odcinek imitacyjny ujmował w sobie dwa pierwsze wersy strofy. 
w Zakonie Pańskim” i „Ale to jego umysł”) nie korespondują z rytmiczno-fakturalnym kształtem początku drugiego odcinka kompozycji (zob. przykł. 2, t. 20-2I); w wypadku przekładu Trzecieskiego deklamowane byłoby: „Ale w Za-” (rozbicie jedności słowa), a z wierszem Kochanowskiego - „Ale to” (niezręcznie z punktu widzenia składni i semantyki). Zdecydowanie zatem za prawidłowy trzeba uznać pierwszy wariant, w którym inicjalny odcinek utworu obejmuje połowę strofy (pierwszy wers wypełnia dziewiętnaście wstępnych taktów, drugi śpiewany jest na zasadzie repetycji odcinka), co oznacza, że cała kompozycja stanowi opracowanie pierwszej strofy psalmu i pół jego drugiej strofy.

Ustalenie to jest pomocne w rozstrzygnięciu najważniejszego dylematu identyfikacyjnego: Trzecieski czy Kochanowski? Klucz do odpowiedzi na to pytanie kryje się przede wszystkim w porównawczym zestawieniu pierwszego członu czwartego wersu pierwszej strofy (Trzecieski: „zdradliwych sie naśmiewcow”; Kochanowski: „Co się z nauki zdrowej”) z przynależnym mu fragmentem muzycznym (zob. przykł. 2, t. 30-34). Słowa Trzecieskiego nie korelują ze składnią muzyczną (deklamacja: „zdradliwych sie na-”), pięciosylabowa cząstka z Kochanowskiego natomiast zgodna jest z muzyczną deklamacją („Co sie z nauki”), choć przy częściowym naruszeniu koherencji semantycznej (tj. bez „zdrowej”), skądinąd w następnych taktach dobitnie zrekompensowanej przez wielokrotne powtórzenia cząstki: „z nauki zdrowej”). Wszystko więc wskazuje, że w Psalmie Dawida umuzyczniony został przekład Jana Kochanowskiego. Przeświadczenie to - graniczące z pewnością - znajduje mocne argumenty zarówno w samej czynności podkładania tekstu słownego pod zapis nutowy (w wypadku wiersza Kochanowskiego jest to operacja dużo bardziej naturalna i stwarzająca mniej problemów, aniżeli analogiczne zabiegi w odniesieniu do słów Trzecieskiego), jak i - co przecież równie istotne - w całościowym rezultacie odtworzenia warstwy słownej.

Jak tedy stwierdzono, z przekładu Kochanowskiego, w całości liczącego pięć czterowersowych strof, opracowaniu muzycznemu poddane zostały pierwsza strofa i dwa pierwsze wersy drugiej strofy. Kompozytor Psalmu Dawida uwzględnił więc inicjalny fragment wiersza obejmujący sześć pierwszych wersów, który przytaczamy w uwspółcześnionej pisowni i w takim brzmieniu podpisujemy pod zapis nutowy:

Szczęśliwy, który nie był miedzy złemi w radzie,

Ani stóp swoich torem grzesznych ludzi kładzie,

Ani siadł na stolicy, gdzie tacy siadają,

Co sie z nauki zdrowej radzi naśmiewają.

Ale to jego umysł, to jego staranie,

Aby na wszytkim pełnił Pańskie przykazanie ${ }^{\mathrm{I}}$.

10 W porównaniu do wersji zamieszczonej u Piotra Artomiusza słowo „adzci” zamieniono na „tacy”, zgodnie z większością historycznych przekazów tekstu (zob. np. Mikołaj Gomółka, Melodie na Psatterz polski. Facsimile pierwodruku, wyd. Mirosław Perz, Kraków 1981, f. 1v). 
Przyporządkowanie tekstu rysuje się zatem następująco: pierwszy odcinek utworu (t. I-I9) ujmuje dwa pierwsze wersy psalmu, przy czym drugi z nich śpiewany jest na zasadzie repetycji odcinka; wersy trzeci i czwarty wypełniają drugi odcinek kompozycji (t. 20-55), a wersy piąty i szósty - odcinek trzeci (t. 56-96). Ponieważ dwa pierwsze odcinki (t. I-55) mają wspólną chiavettę, którą tworzą klucze: wiolinowy (G2), sopranowy $\left(\mathrm{CI}_{1}\right)$, altowy $\left(\mathrm{C}_{3}\right)$, barytonowy $\left(\mathrm{F}_{3}\right)$, nadto odcinek drugi kończy się wartością longi z fermatą (t. 55), a z kolei odcinek trzeci (t. 56-96) ma inny zestaw kluczy: wiolinowy $\left(\mathrm{G}_{2}\right)$, mezzosopranowy $\left(\mathrm{C}_{2}\right)$, altowy $\left(\mathrm{C}_{3}\right)$, barytonowy $\left(\mathrm{F}_{3}\right)$, to partię obejmująca dwa pierwsze odcinki (t. I-55) uznajemy za prima pars kompozycji, a odcinek trzeci (t. 56-96) za jej secunda pars. Głosom nadajemy nazwy: Cantus, Altus, Tenor, Bassus. Przedstawiona transkrypcja Psalmu Dawida (zob. przykł. 2) sporządzona została według standardów edycji źródłowo-krytycznej ${ }^{\mathrm{II}}$.

Przykł. 2. Psalm Dawida, transkrypcja przekazu źródłowego z rekonstrukcją warstwy słownej

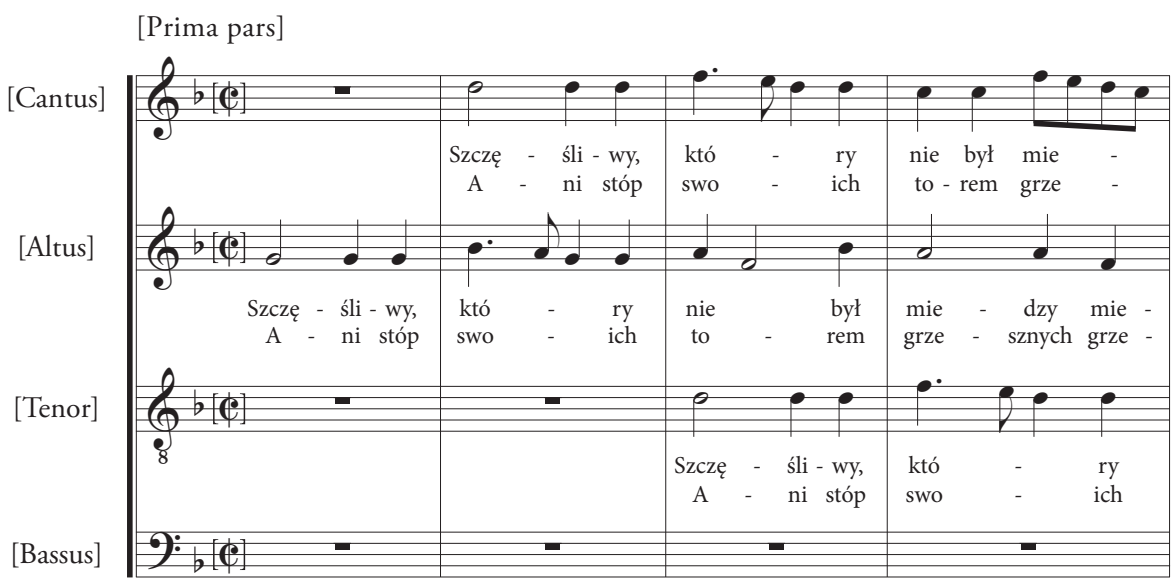

11 Klucze sopranowy (C1) i mezzosopranowy (C2) zostały zastąpione kluczem wiolinowym (G2), klucz altowy (C3) - kluczem wiolinowym z przenośnikiem oktawowym w dół, klucz barytonowy (F3) - kluczem basowym (F4). Zachowano wartości nutowe i rozmiary taktu z przekazu źródłowego. Brakujące akcydencje wprowadzono przed nutą w nawiasie kwadratowym; akcydencja taka obowiązuje w całym takcie. Akcydencje prawdopodobne zaznaczono nad nutą; akcydencja taka odnosi się tylko do tej nuty, nad którą jest umieszczona. Nuty o wartości longi kończące prima pars i secunda pars zamieniono na nuty o wartości brevis. Wykaz korektur: 9. T; nad 1: krzyżyk; 17. A; przed 4: bemol; 18. C; przed 3: krzyżyk; 19. T; przed 1: krzyżyk; 21. T; pod 1: krzyżyk; 21. T; pod 2: krzyżyk; 22. T; przed 2: krzyżyk; 36. A; nad 4: krzyżyk; 38. T; przed 4: krzyżyk; 40. A; pod 4: krzyżyk; 40. T; pod 3: krzyżyk; 46. A; nad 4: krzyżyk; 47. T; nad 4: krzyżyk; 48. T; pod 2: krzyżyk; 48. T; pod 4: krzyżyk; 50. A; pod 4: krzyżyk; 50. T; pod 3: krzyżyk; 53. A; 2: es ${ }^{1}$; 92. A; przed 3: bemol; 94. A; 2: a; 95. C; pod 4: krzyżyk; 95. A; $1: b$; 96. A; przed 1: krzyżyk; 96. T; przed 1: krzyżyk. 

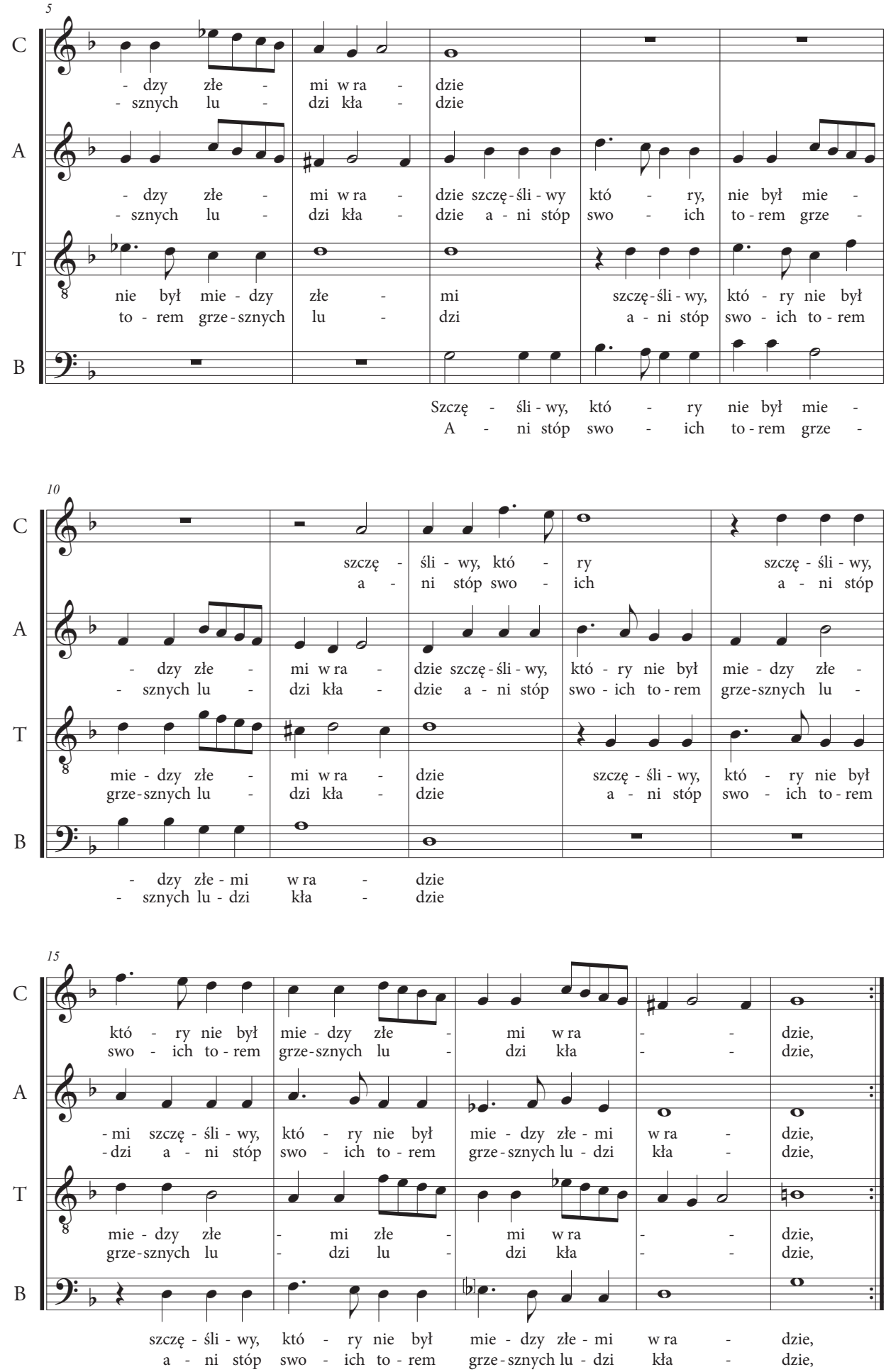


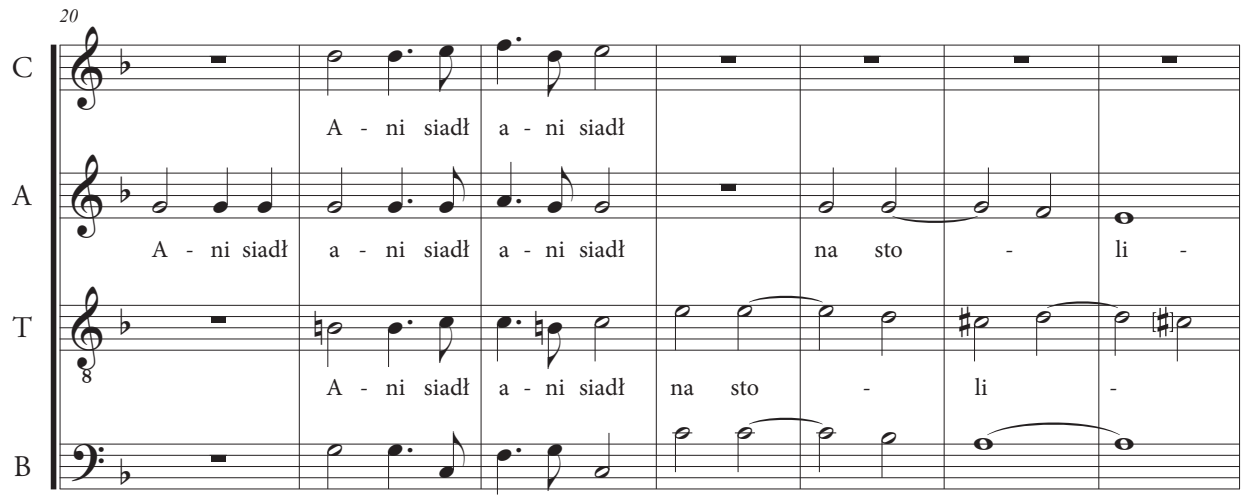

A - ni siadł a - ni siadł na sto $\quad$ - n li

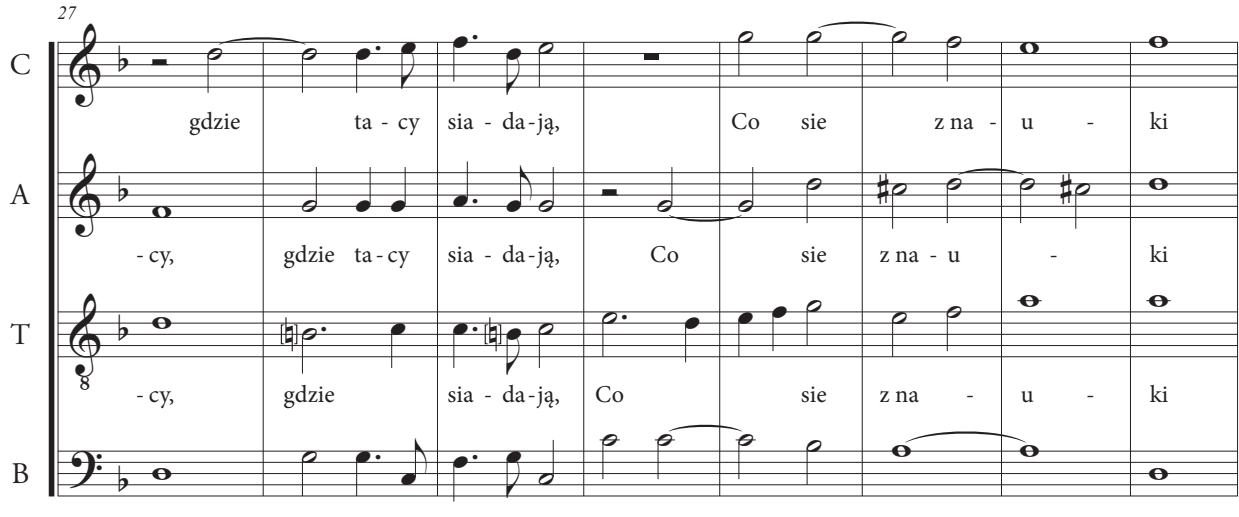

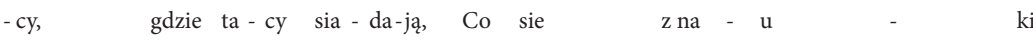

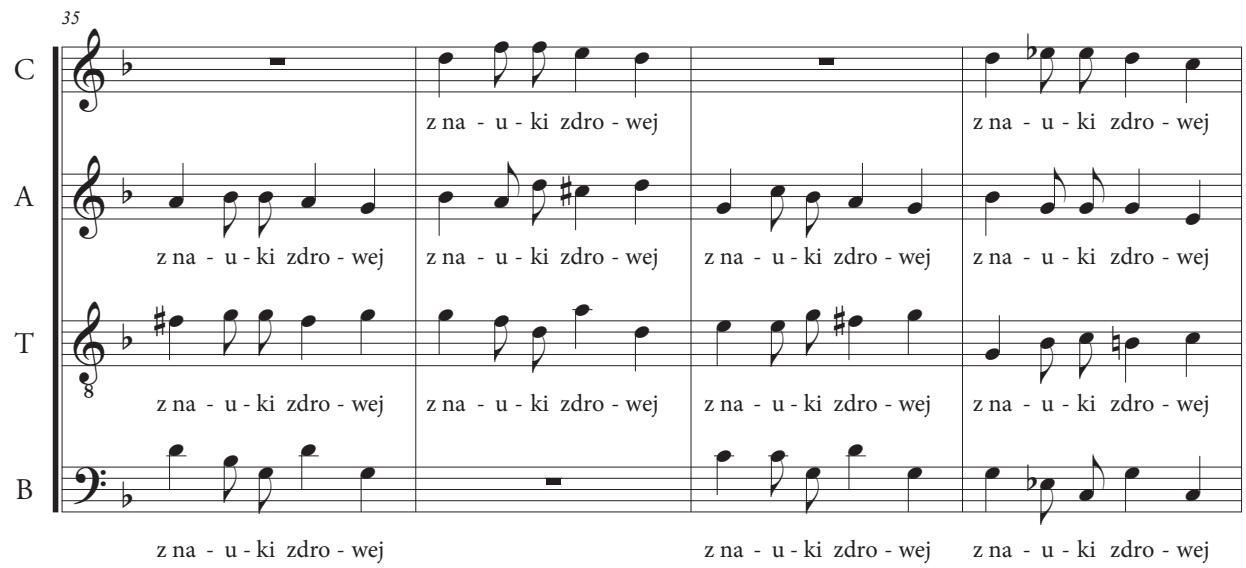




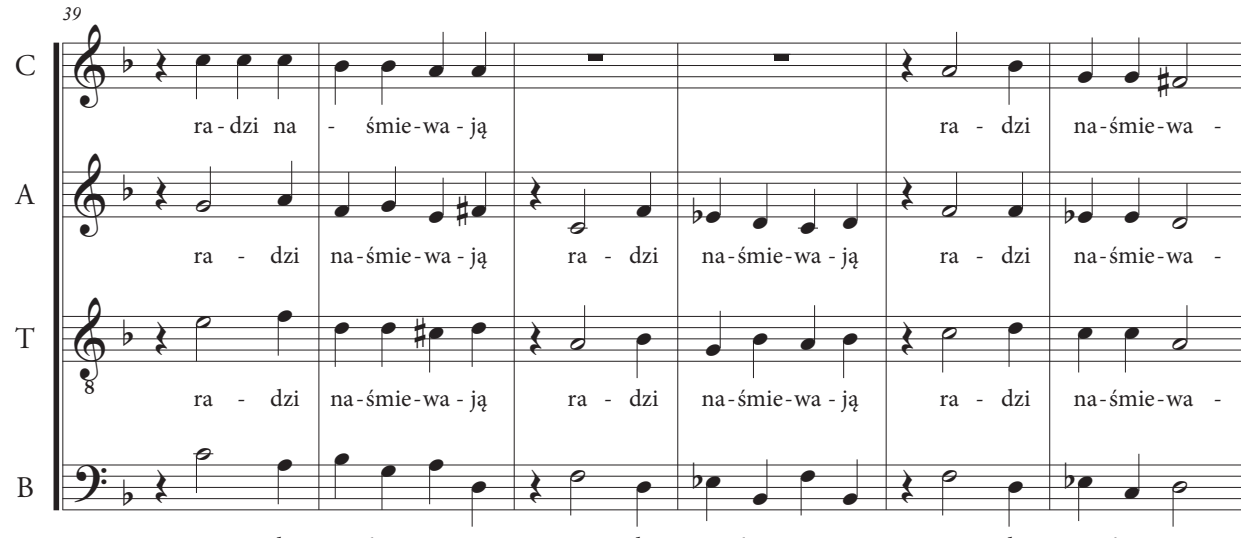

ra - dzi na-śmie-wa-ją ra - dzi na-śmie-wa-ją ra - dzi na-śmie-wa -
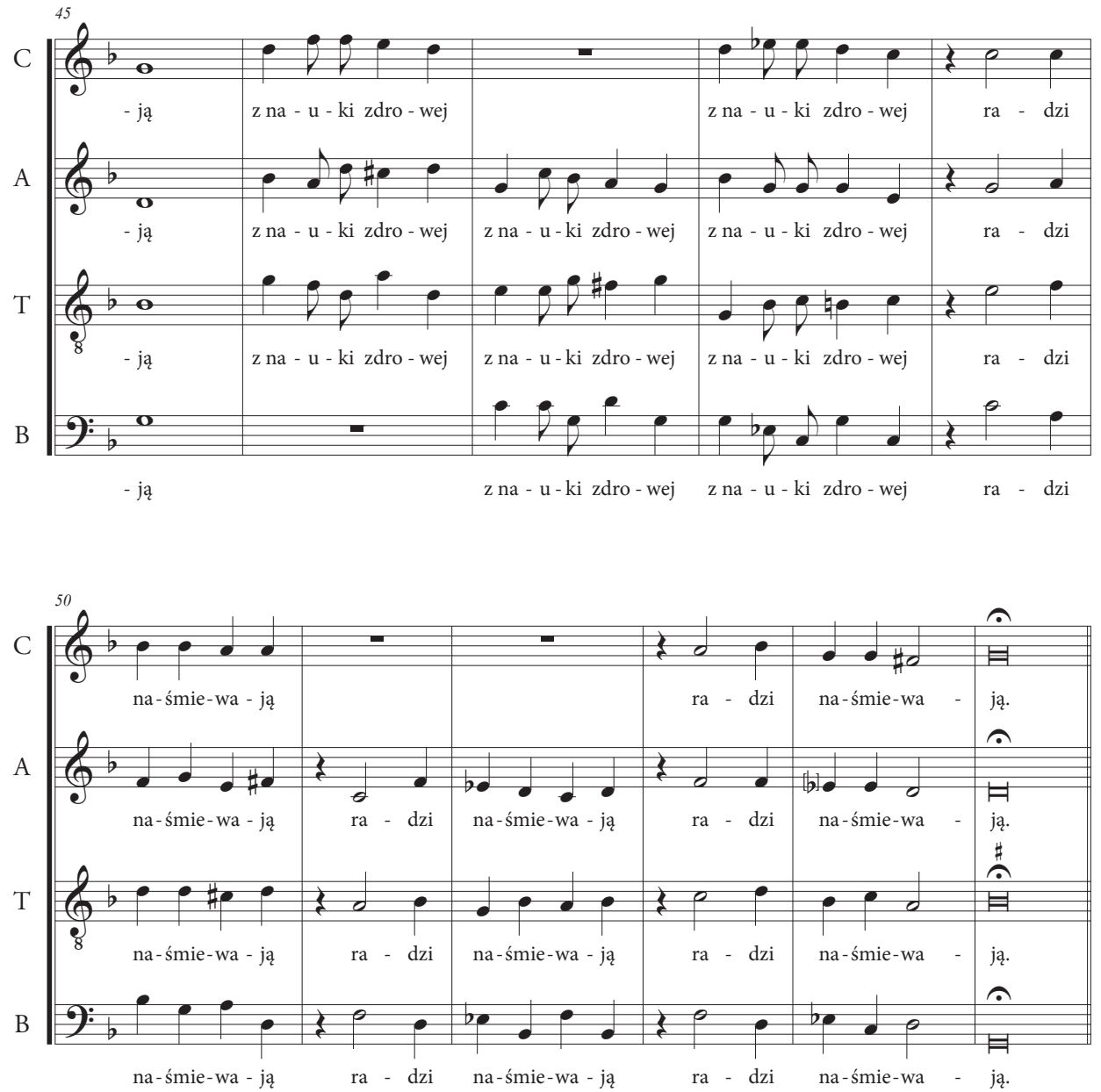
[Secunda pars]
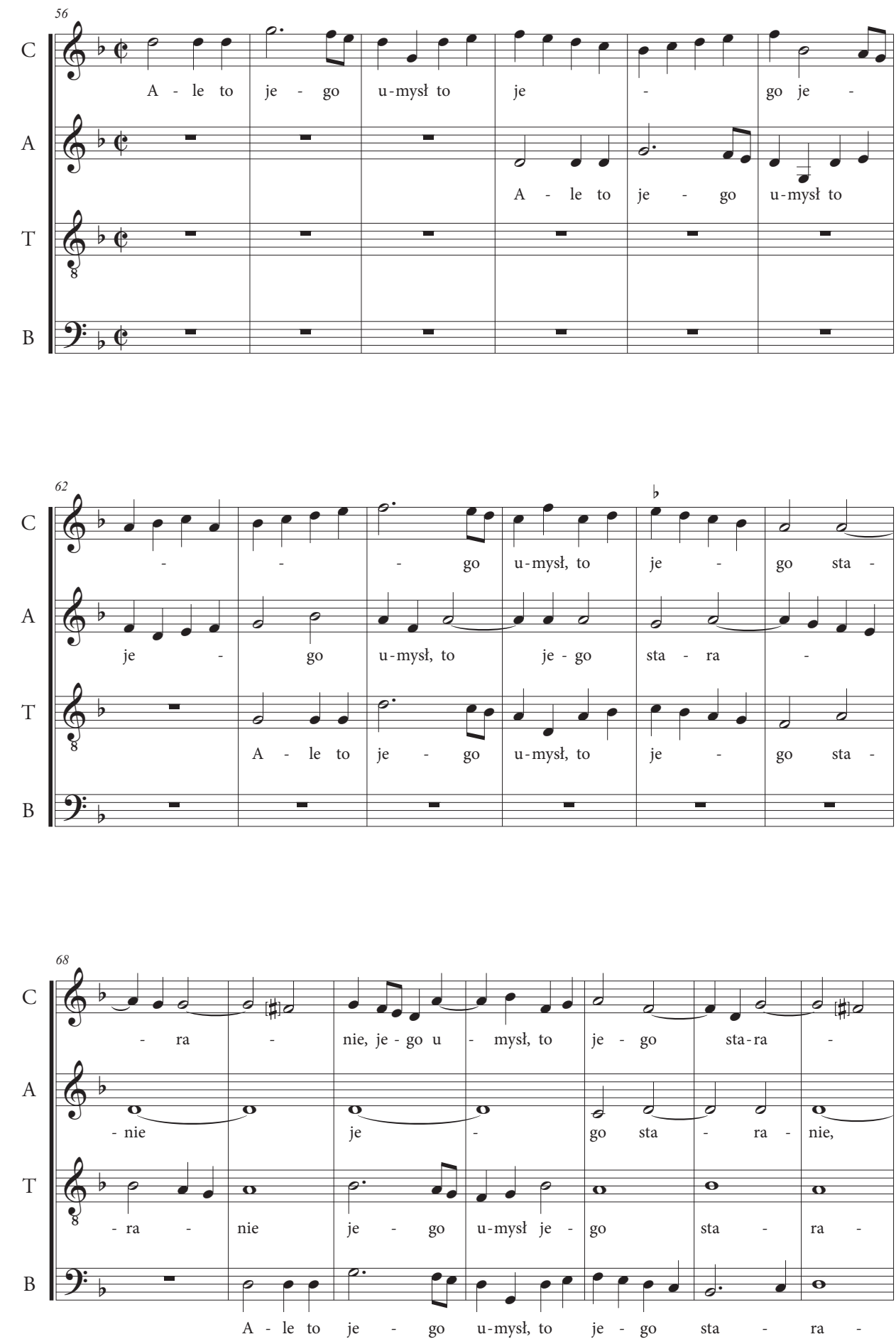


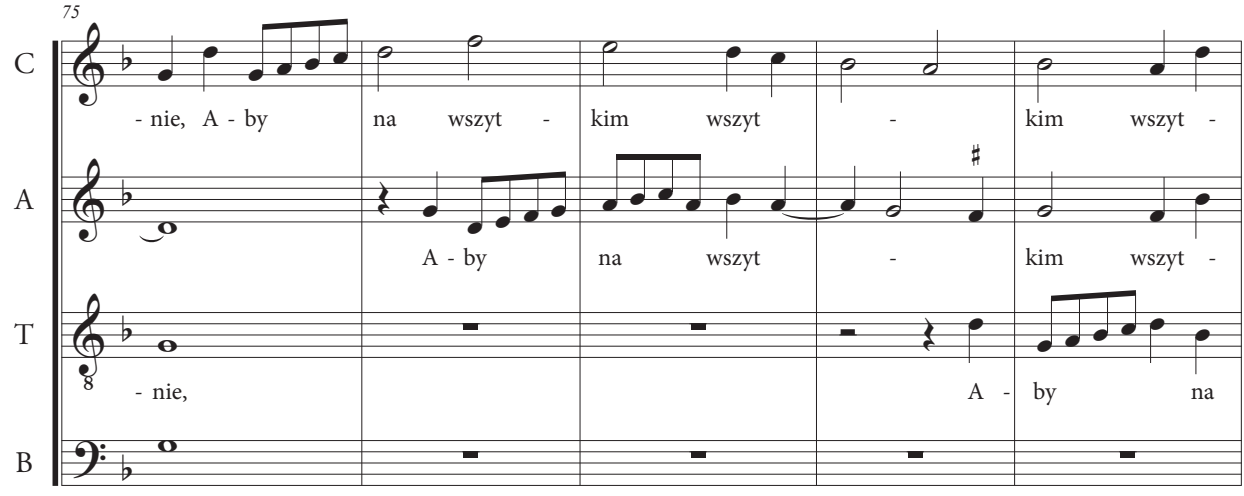

- nie,

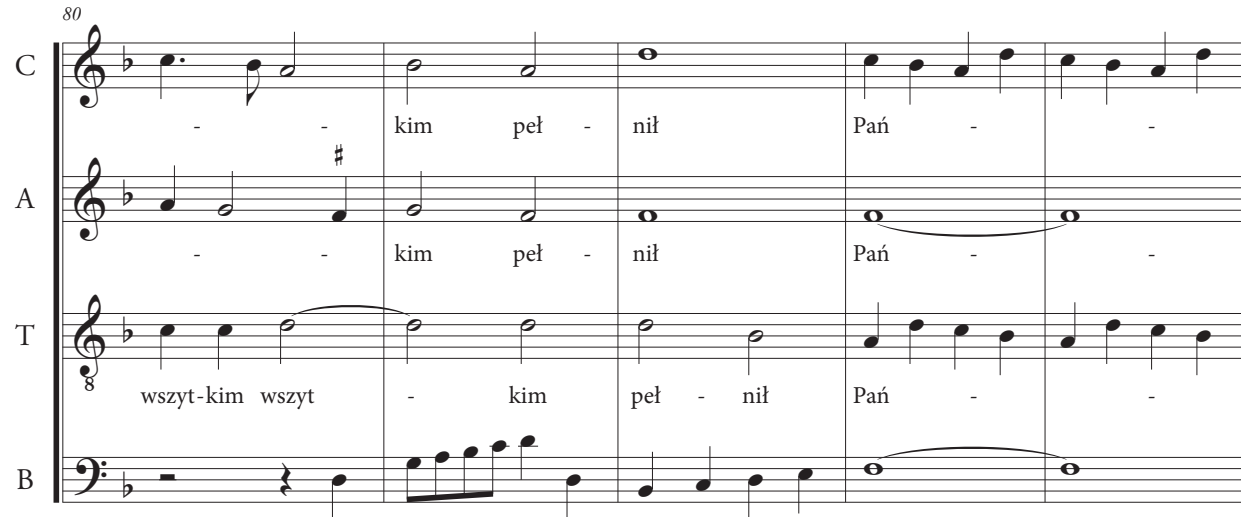

A - by na wszyt-kim peł - nił Pań

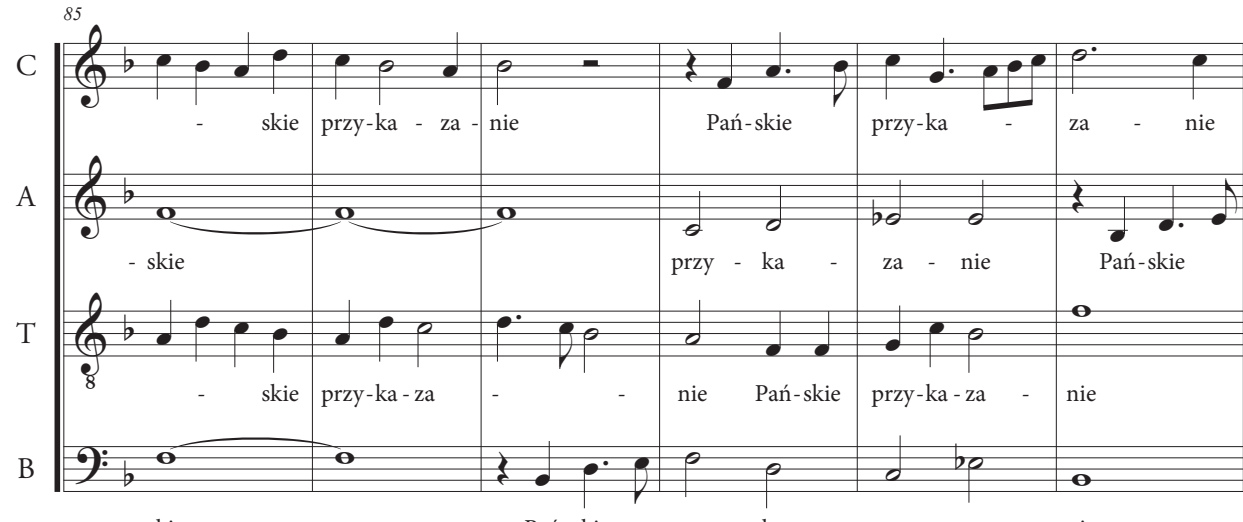

- skie Pań-skie przy - ka - za - nie 


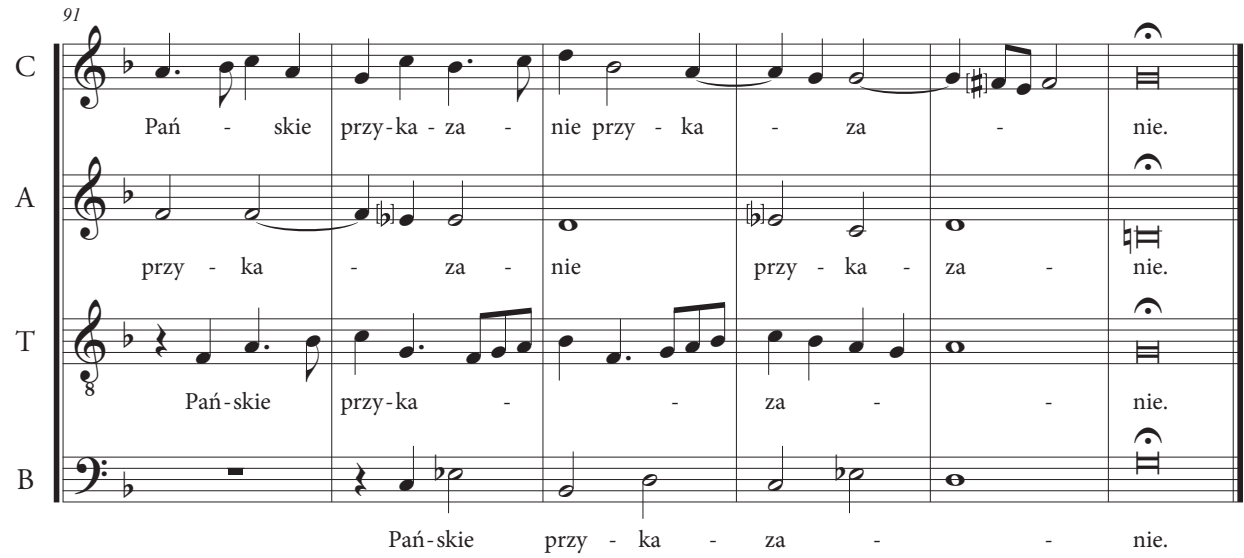

Niezbędne są w tym miejscu wyjaśnienia dotyczące sposobu podłożenia słów. W prima pars sytuacja jest prawie jednoznaczna; można by dyskutować jedynie o nielicznych, choć równocześnie bardzo ważnych detalach ${ }^{\mathrm{r2}}$. Łatwość podłożenia słów, szczególnie $\mathrm{w}$ drugim odcinku prima pars (t. 20-55), wynika z dominacji toku sylabicznego. Zgoła inaczej jest $\mathrm{w}$ secunda pars. Tu - z uwagi na duży udział toku melizmatycznego w większym stopniu trzeba było odwołać się do intuicji. Toteż zdaję sobie sprawę, że w odniesieniu do tej fazy utworu, zwłaszcza do t. 57-85, mogą zostać wskazane inne rozwiązania. Przyjmując tedy za niemal pewne, iż Psalm Dawida to kompozycja stworzona do wiersza Szczęśliwy, który nie byt miedzy ztemi w radzie pióra Jana Kochanowskiego, dodajmy zastrzeżenie: niektóre zaproponowane rozwiązania w zakresie podłożenia słów muszą pozostać tylko propozycjami ${ }^{13}$.

Gdy chodzi o kwestię prawidłowości przekazu źródłowego i poprawności sporządzonej transkrypcji, napotykamy na nieliczne tylko wątpliwości lub usterki wymagające korekt. Być może w t. 39 w sopranie powinna być grupa: pauza ćwierćnutowa - półnu-

12 W prima pars właściwie jedyna wątpliwość dotyczy sposobu podłożenia tekstu „Szczęśliwy, który nie był miedzy złemi w radzie” pod pierwszą frazę tematyczną (t. 1-19). Kluczowa kwestia w tym wypadku to: zdecydować się w drugim takcie frazy na tok ściśle sylabiczny czy dla sylaby „któ-” przyjąć trzydźwiękowy melizmat, umieszczając sylabę „-ry” pod ostatnią nutą taktu? Analiza zależności uporządkowań rytmiczno-melodycznych wszystkich głosów na przestrzeni całego odcinka dowodzi, że zasadnicza postać frazy „Szczęśliwy, który nie był” powinna być wyposażona we wspomniany melizmat (i taki jej kształt przyjęto w transkrypcji), ale w kolejnych pokazach frazy (tj. od t. 12) jej czoło przybiera kształt sylabiczny.

13 Gdy chodzi o kwestię podłożenia tekstu słownego w secunda pars, wątpliwości pojawiają się przede wszystkim w przeprowadzeniu pierwszej frazy tematycznej (t. 56-74), bezsprzecznie rozwijającym się z dużym udziałem toku melizmatycznego. Po przeprowadzeniu drugiej frazy tematycznej (t. 75-82), pod względem deklamacyjnym dość jednoznacznym, powstaje trudny do rozstrzygnięcia dylemat: w t. 83-85 w sopranie i tenorze pojawia się - całkowicie odbiegająca od normy melodycznej utworu - struktura rotacyjno-cyrkulacyjna (dwukrotne powtórzenie czterodźwiękowej struktury melodycznej na tym samym stopniu); nie wiadomo, czy wiązała się ona z tokiem sylabicznym, sylabiczno-melizmatycznym czy melizmatycznym. W transkrypcji zdecydowałem się na ten ostatni wariant, synchronizując deklamację słowa „Pańskie” z altem i basem. 
ta - ćwierćnuta (a nie, jak przyjęto: pauza ćwierćnutowa - trzy ćwierćnuty), tj. tak, jak widzimy to w ponownym wystąpieniu całej struktury wielogłosowej w t. 49 . Ostatecznie jednak opowiadam się w tym wypadku za przekazem źródłowym, tj. za wariantem z trzema ćwierćnutami. W t. 92 z kolei, w alcie, bemol postawiony jest przed półnutą $e^{\mathrm{I}}$. Jeśliby trzymać się literalnie źródła, to powinien zaistnieć $\mathrm{w}$ tym miejscu pochód chromatyczny: $e^{\mathrm{I}}$ (ćwierćnuta) - es $s^{\mathrm{I}}$ (półnuta), równocześnie pojawiłoby się w tym miejscu niekonwencjonalnie brzmiące następstwo współbrzmień: $c-g-e^{\mathrm{I}}-c^{2}$ i $e s-g-e s^{\mathrm{I}}-b^{\mathrm{I}}$, odbiegające od normy harmonicznej utworu. Wydaje się wszakże, iż bemol postawiony $\mathrm{w}$ źródle przed półnutą $e^{\mathrm{I}}$ odnosi się również do nuty poprzedniej, toteż winien on figurować przed ćwierćnutą $e^{\mathrm{I}}-\mathrm{i}$ tak też przyjęto w transkrypcji. Ewidentny wreszcie błąd w przekazie źródłowym zachodzi na antepenultimie i penultimie klauzuli altu w t. 94-95. W zapisie źródłowym mamy tu kolejno dźwięki: a (druga nuta w t. 94) i $b$ (t. 95). Bez wątpienia powinny być tu wysokości: $c^{\mathrm{I}}$ i $d^{\mathrm{I}}$; oba wskazane dźwięki kopista wpisał o tercję za nisko. Są to w istocie jedyne miejsca, które wiążą się z uchybieniami zapisu źródłowego bądź nasuwają wątpliwości wymagające wyjaśnień.

Psalm Dawida jest utworem na tyle interesującym i wyróżniającym się na tle zachowanego repertuaru muzyki staropolskiej, że warto zatrzymać się przy kilku jego aspektach. Przede wszystkim mamy przed sobą kompozycję motetową w języku polskim. Jeśli spojrzymy na polskojęzyczny repertuar wielogłosowy z czasu renesansu i baroku, odnotowujemy, po pierwsze, skromny ilościowo dorobek w tym zakresie (zwłaszcza w odniesieniu do XVII w.), po drugie - co trzeba podkreślić - całkowitą dominację form pieśniowych (m.in. pieśni Cypriana Bazylika, Tomasza Bielawskiego, Mikołaja Gomółki, Krzysztofa Klabona, Sebastiana Klonowica, Franciszka Liliusa, Wacława z Szamotuł). Nawet jeżeli niektóre z tych utworów oddalają się od prostej homorytmii w stronę nieco bardziej złożonej tkanki polifonicznej (np. przez udział imitacji czy wzmożenie linearyzmu), to pozostają one, głównie z uwagi na małe rozmiary i dystans wobec techniki przeimitowania, w idiomie pieśniowym. Zasadniczo, przy obecnym stanie wiedzy, brak jest innego rodzaju utworów polskojęzycznych - motetów, madrygałów lub innych, mniej lub bardziej rozbudowanych form ${ }^{\mathrm{I}}$. Dlatego Psalm Dawida, jako kompozycja motetowa z tekstem w języku ojczystym, jest nowością gatunkową w polskiej muzyce dawnej.

Drugi aspekt wiąże się z faktem, że - o ile trafnie wskazałem podstawę tekstową wraz z Psalmem otrzymujemy nieznaną dotąd kompozycję do poezji Jana Kochanowskiego. Obecność jego psalmowych przekładów w Melodiach na Psatterz polski Mikołaja

14 Wyjątkiem jest tu anonimowy Hymn rokoszan Zebrzydowskiego, odznaczający się większymi rozmiarami, kontrastami i onomatopeicznym charakterem, zob.: Barbara Przybyszewska-Jarmińska, Barok, część pierwsza: 1595-1696, Warszawa 2006 (= Historia Muzyki Polskiej 3), s. 427-431. 
Gomółki oraz pojedynczych pieśni, psalmów i kilku innych wierszy w twórczości muzycznej XVI-XVII w. ${ }^{\text {I5 }}$ wiąże się bez wyjątku ze stylem pieśniowym. Tu natomiast mamy okazję poznać motet z poezją Kochanowskiego. Jawi się on na tle wszystkich do tej pory znanych muzycznych opracowań poezji mistrza z Czarnolasu jako pozycja prawdziwie unikatowa. Psalm Dawida jest bowiem polskojęzycznym odpowiednikiem łacińskiego motetu; można go określić mianem polskiego motetu psalmowego. Przy obecnym stanie znajomości repertuaru muzycznego epoki staropolskiej nie da się wskazać analogicznej pod względem formalno-gatunkowym kompozycji do poezji Jana Kochanowskiego; dodajmy równocześnie ani też do wiersza w języku ojczystym jakiegokolwiek innego ówczesnego poety polskiego.

Trzecia uwaga dotyczy wartości artystycznej Psalmu. Utwór odznacza się nienagannym warsztatem kontrapunktycznym, bardzo dobrym prowadzeniem głosów, pełnią brzmienia, klarownym przebiegiem tonalnym. Odsłania z jednej strony spójność motywiczną, wynikającą ze zbieżności motywów inicjalnych głównych odcinków utworu (por. t. I-2, 20, 56-57) ${ }^{16}$ i z nadkompletnej imitacji syntaktycznej (zob. t. I-I9, 56-74), z drugiej natomiast strony ujawnia wewnętrzną różnorodność, osiągniętą przez wprowadzenie kontrastów rytmicznych i deklamacyjnych odcinków homorytmicznych (zob. t. 20-55). Za sprawą owego skontrastowania utwór nosi w sobie także cechy madrygału (zwłaszcza w t. 20-55), zasługując tym samym na miano motetu madrygałowego. Nie można wreszcie przeoczyć wyrazowych koherencji słowno-muzycznych. Są to m.in.: dłuższe wartości nutowe na słowach „poważnych” (,stolicy” w t. 23-27, „nauki” w t. 30-34) czy - zdecydowanie odbiegająca od normy melodycznej dzieła - sekwencja trzech wystąpień na tym samym stopniu czteronutowego motywu w sopranie i tenorze, połączona z imitacją kanoniczną (w całości jest to swoista struktura rotacyjno-cyrkulacyjna) i rozbrzmiewająca na tle tenuto altu i basu, ze słowem „Pańskie” - symbolicznie odsyłająca do Boga (t. 83-85/86). Oczywiście w stosunku do sfery dźwiękowej interpretacji tekstu należy zachować daleko idącą powściągliwość, przede wszystkim ze względu na supozycyjną jednak obecność tekstu Kochanowskiego. Ale w tym miejscu zauważmy jedno: właśnie istniejące koherencje słowno-muzyczne (można tu jeszcze wskazać na zbieżność kształtów dźwiękowych w ujęciach słów „Ani siadł” i „gdzie tacy siadają" w t. 2I-22 i 29-29) są dodatkową przesłanką, by ostatecznie nabrać przekonania, że Psalm rozbrzmiewał z poezją Jana Kochanowskiego.

15 Zob.: Ewa Ostaszewska, „Kochanowski Jan”, w: Encyklopedia Muzyczna PWM, red. Elżbieta Dziębowska, t. 5, Kraków 1997, s. 114-115.

16 Warto na marginesie zwrócić uwagę na fakt, że chociaż materiał prekompozycyjny legł u podstaw jedynie prima pars motetu, to pierwsza fraza tematyczna secunda pars ściśle nawiązuje do inicjalnej frazy Psalmu, co integruje materiałowo całość formy. 
Stawiam tezę, że Psalm Dawida mógł skomponować Mikołaj Gomółka. Od przeświadczenia tego nie mogę się uwolnić i dlatego - całkowicie świadom ryzyka badawczego - pragnę zmierzyć się z analizą porównawczą zestawiającą Melodie na Psatterz polski z anonimowym utworem. Dyskurs na ten temat rozpocznę wszakże przewrotnie: od wypunktowania zjawisk, które przeczą potencjalnemu autorstwu Gomółki.

Psalm Dawida nie nawiązuje do idiomu muzycznego Melodii na Psatterz polski. Żaden z psalmów Gomółki nie zdradza stylistycznego pokrewieństwa z motetem, co w pierwszym rzędzie wynika z przewagi imitacji syntaktycznej w Psalmie, której to u Gomółki brak. Ale nie tylko to. Dystans Psalmu wobec Melodii jest daleko większy i głębiej sięgający, aniżeli ten, który wynika z różnic między użytymi technikami kompozytorskimi. W Psalmie znajdujemy takie zjawiska, które są całkowicie obce Melodiom. W ani jednym psalmie Gomółki nie ma redukcji faktury do trójgłosu, podobnie jak bezpośredniej konfrontacji trójgłosu górnego i trójgłosu dolnego, co odgrywa tak istotną rolę w Psalmie (np. t. 35-37, 46-47). Zasadniczo obce jest też Gomółce posługiwanie się schematami rytmicznymi, regularnie powtarzanymi z taktu na takt (por. Psalm Dawida, t. 35-38, 46-48, 49-52). Gdy chodzi o ukształtowania kadencyjne, warto podkreślić, że kadencje doskonałe u Gomółki, zwłaszcza końcowe (choć także często i wewnętrzne), w przeważającej większości zawierają przejściową septymę, tj. na tle akordu dominantowego pojawia się na krótkiej wartości nutowej septyma mała, rozwiązująca się następnie na tercję toniki. W Psalmie Dawida nie zachodzi to ani razu, choć kadencji i zwrotów kadencyjnych jest w nim sporo. Zasadniczo nie ma też w motecie, co dość często występuje u Gomółki, niekonwencjonalnych połączeń harmonicznych, jakkolwiek gdzieniegdzie - trzeba to odnotować - spotyka się w Psalmie bezpośrednie następstwa równoimiennych trójdźwięków minorowych i majorowych (t. 34-35) oraz ukośne brzmienia półtonu (t. 40-4I, 50-5I), przypadające wszelako w miejscach cezur, tj. po kadencji albo po pauzie generalnej. W Psalmie odnotowujemy ponadto wielokrotne powtórzenia fragmentów tekstu w wewnętrznym biegu kompozycji (zwłaszcza t. 35-55), czego Gomółka nie stosuje. Rozmaitych różnic pomiędzy Psalmem a Melodiami można by wskazać więcej.

A mimo wszystko wątek Gomółki warto podjąć. Przy licznych bowiem odmiennościach ujawniają się między Melodiami na Psatterz polski a Psalmem Dawida tego rodzaju pokrewieństwa i zbieżności, które muszą zastanawiaćr ${ }^{7}$.

17 Prezentowane w niniejszym tekście przykłady nutowe sporządziłem na podstawie edycji: Mikołaj Gomółka, Melodie na Psatterz polski przektadania Jana Kochanowskiego. Transkrypcja, wyd. Mirosław Perz, opr. krytyczne tekstu Jerzy Woronczak, Kraków 1983. Równocześnie jednak odsyłam do źródłowego zapisu z pierwodruku Melodii (M. Gomółka, Melodie na Psatterz polski. Facsimile), ponieważ oryginalny zapis (z dwukrotnie większymi wartościami nutowymi) jeszcze sugestywniej odsłania niektóre ze stwierdzonych zbieżności. 
Pierwszy punkt styczny - do pewnego stopnia zewnętrzny, sam w sobie może nie tak znaczący - to kształt inicjalnej frazy tematycznej Psalmu, a w istocie, jej pierwszych dwóch taktów. „Szczęśliwy” to trzy dźwięki tej samej wysokości - półnuta i dwie ćwierćnuty; „który” (w innych wystąpieniach: „który nie byl”) - to skok o tercję małą w górę i sekundowe jej wypełnienie w kierunku przeciwnym:

Przykł. 3. Psalm Dawida, Altus, t. I-2

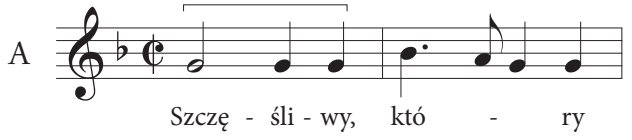

U Kochanowskiego sześć psalmów rozpoczyna się słowem „Szczęśliwy/Szczęśliwi” (psalmy: I, XXXII, XLI, CXII, CXIX, CXXVIII), z których pięć Gomółka inicjuje w bliźniaczy sposób, wychodząc od takiego repetycyjnego modelu, jaki widzimy w Psalmie Dawida:

Przykł. 4a. Mikołaj Gomółka, Psalm CXIX, Cantus, t. I-2

C

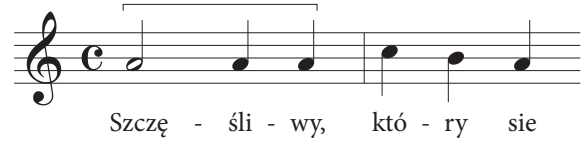

Przykł. 4b. Mikołaj Gomółka, Psalm I, Cantus, t. I-4

C

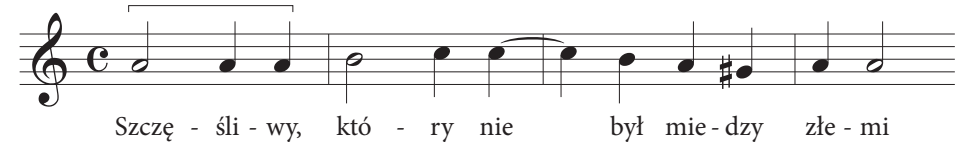

Przykł. 4c. Mikołaj Gomółka, Psalm XXXII, Cantus, t. I-4

C

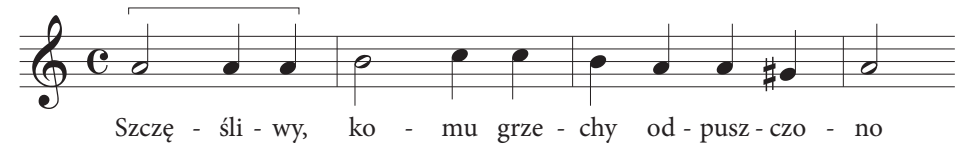

Przykł. 4d. Mikołaj Gomółka, Psalm XLI, Cantus, t. I-5

$\mathrm{C}$

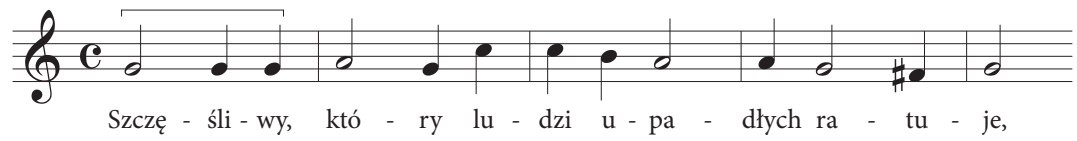


Przykł. 4e. Mikołaj Gomółka, Psalm CXXVIII, Cantus, t. I-3

$\mathrm{C}$

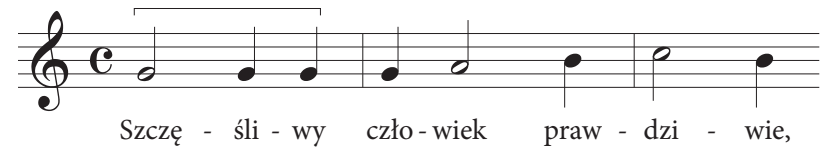

Naturalnie nie można pominąć faktu, że nie tylko psalmy zaczynające się od „Szczęśliwy”/„Szczęśliwi” wyrastają u Gomółki z owego repetycyjnego motywu, skądinąd tak charakterystycznego dla chanson i canzony. Jest on u tego kompozytora na tyle częstą formułą inicjalną, iż można powiedzieć, że wręcz dla niego typową ${ }^{18}$. Niemniej incipit „Szczęśliwy”/„Szczęśliwi” ujmowany jest przez Gomółkę prawie każdorazowo według jednej idei meliczno-rytmicznej; jakby swoim pojawianiem się samorzutnie wyznaczał określony rysunek melodyczny: repetycje w manierze początków canzony i chanson (przykł. 4a-e) - skok o tercję małą w górę lub wypełnienie jej ruchem sekundowym (przykł. 4a--c) albo, analogicznie, o kwartę w górę (przykł. 4d-e) stopniowy powrót do punktu wyjścia ruchem łącznym (przykł. 4a-d). Z rysunkiem tym ściśle koresponduje pierwsza fraza Psalmu.

Wskazując na kolejne pokrewieństwa kształtów, chcę wszakże zasadniczo zdystansować się od tekstu słownego i skupić na relacjach czysto dźwiękowych, ponieważ tekst Jana Kochanowskiego - przy całym moim przekonaniu co do trafności poczynionej identyfikacji - pozostaje jednak w Psalmie składnikiem supozycyjnym; jakkolwiek, co zobaczymy, i sam tenże tekst może niekiedy dodatkowo naświetlić niektóre zbieżności i podobieństwa dźwiękowe.

Najpierw przypomnijmy krótki fragment homorytmiczny z Psalmu Dawida:

Przykł. 5. Psalm Dawida, t. 2I-22

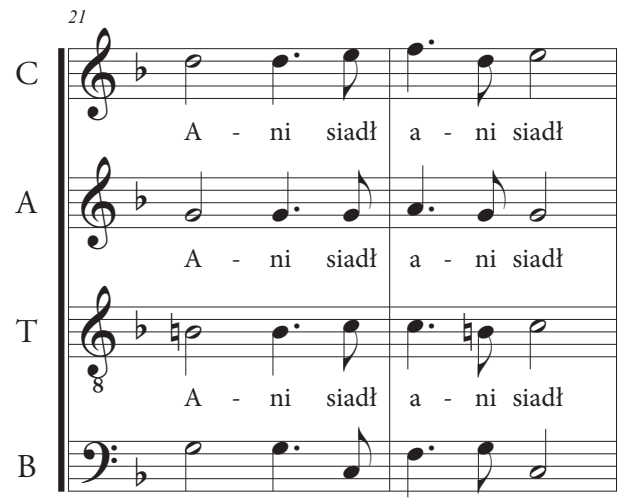

A - ni siadł a - ni siadł

18 Zob. też: Mirosław Perz, Mikotaj Gomótka. Monografia, Kraków 1981, s. 224-225. 
W Melodiach okazjonalnie pojawiają się tego typu kształty rytmiczno-deklamacyjne, dość często jako następstwo: półnuta - ćwierćnuta z kropką - ósemka, wyjątkowo także $\mathrm{z}$ bezpośrednim powtórzeniem rytmu punktowanego:

Przykł. 6a. Mikołaj Gomółka, Psalm LXXVII, t. 5-6

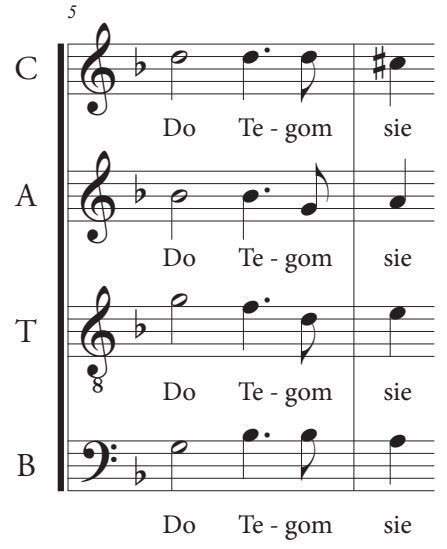

Przykł. 6b. Mikołaj Gomółka, Psalm LXXX, t. I-2

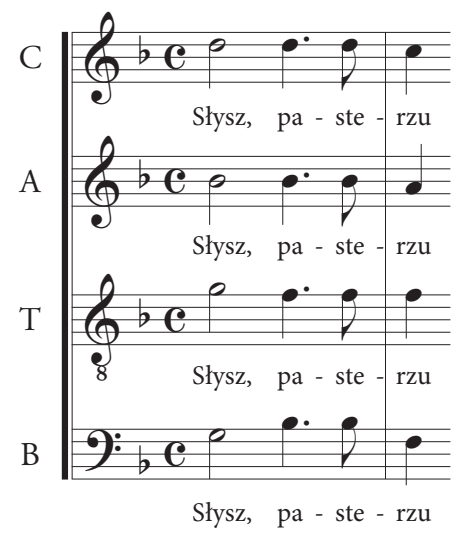


Przykł. 6c. Mikołaj Gomółka,

Psalm LXXVI, t. 4-5

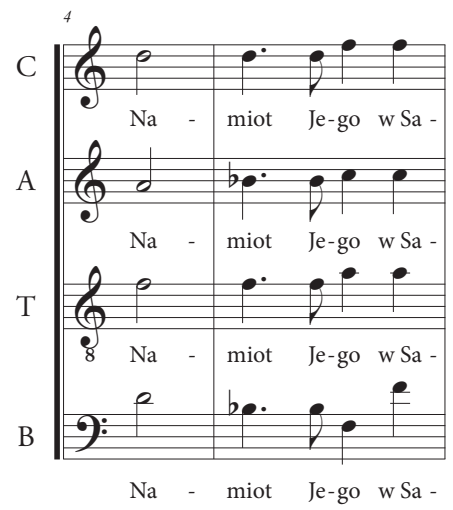

Przykł. 6e. Mikołaj Gomółka,

Psalm LXXXVII, t. 4-6

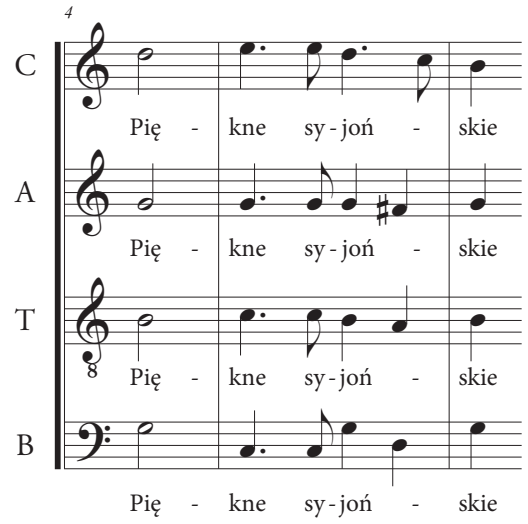

Przykł. 6d. Mikołaj Gomółka,

Psalm XXXIIII, t. 8-9

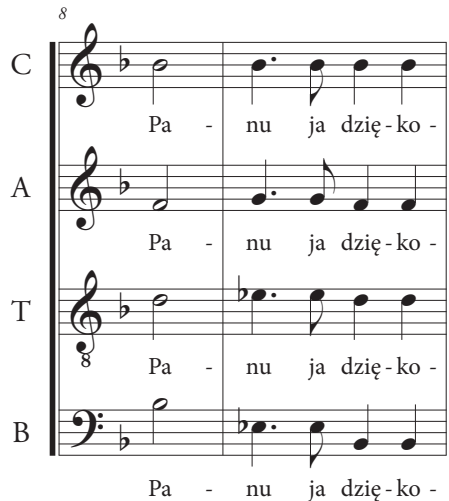

Przykł. 6f. Mikołaj Gomółka,

Psalm XCVIII, t. 5-6

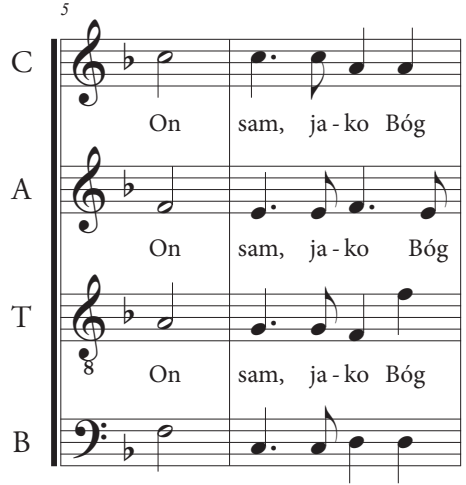

On sam, ja-ko Bóg

Przykł. 6g. Mikołaj Gomółka, Psalm XCIX, t. 5-7

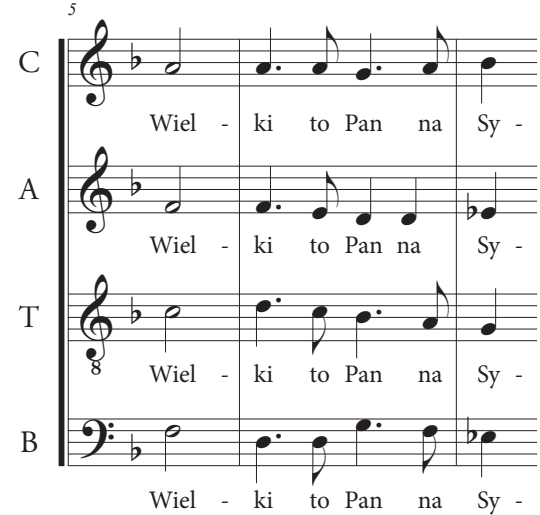


Tego rodzaju struktury, sprzyjające plastycznej deklamacji tekstu, implikujące rytmiczne napięcie, nie pojawiają się u Gomółki uderzająco często, wszelako w kilku miejscach wyraźnie zaznaczają swoją obecność, podobnie jak możemy to zaobserwować w Psalmie (zob. t. 2I-22, 28-29).

W uzupełnieniu tej obserwacji i w nawiązaniu do powyższego fragmentu Psal$m u$ (zob. przykł. 5) odnotujmy pokrewieństwo w deklamacyjno-rytmicznym ujęciu słowa „ani”. U Gomółki dwukrotnie widzimy podobne wydłużenia pierwszej sylaby słowa w układzie nota contra notam:

Przykł. 7a. Mikołaj Gomółka,

Psalm I, t. 9-10

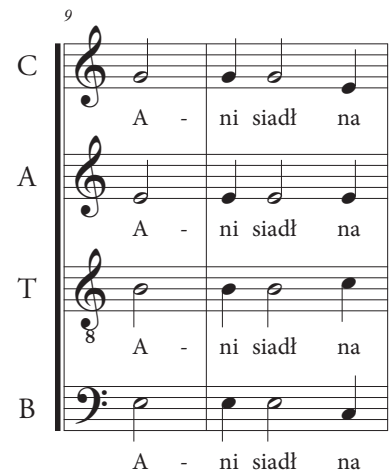

Przykł. 7b. Mikołaj Gomółka,

Psalm CXXXI, t. 9-10

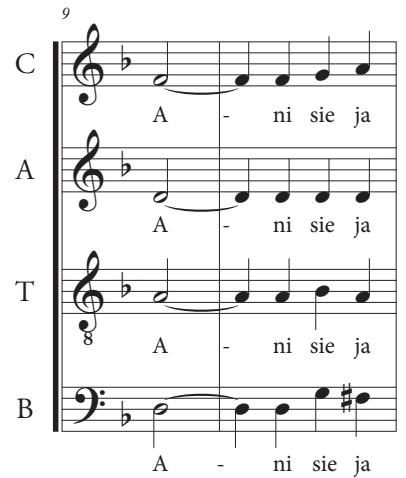

Innego rodzaju zbieżności możemy odnaleźć w takich fragmentach, które nie są jakoś specjalnie uwydatnione pod względem formalnym, tematycznym czy wyrazowym. W większym stopniu są one strukturami „przypadkowymi”, przygodnymi, mającymi „wewnętrzny” udział w rozwijaniu akcji dźwiękowej, które kompozytor kreśli niejako mimochodem, bezwiednie, w różnych miejscach swoich utworów. Pojawiają się one na zasadzie takiego „pociągnięcia pędzlem”, które nie oznacza niczego szczególnego ani doniosłego - jawi się jako „zwykły”, bez mała rutynowo wprowadzany element „obrazu” ${ }^{\text {I9 }}$. Struktury tego rodzaju nie są ani charakterystyczne, ani nie wytwarzają w dziele jakiegoś punktu dystynktywnego. Spójrzmy najpierw na lapidarną, opartą na zwrocie kadencyjnym, strukturę z Psalmu Dawida:

19 W podejściu przypisującym duże znaczenie owym „przypadkowym” kształtom dźwiękowym dla atrybuowania anonimowych dzieł nawiązuję do dziewiętnastowiecznych koncepcji włoskiego znawcy malarstwa Giovanniego Morellego (1816-1891). Zob. Edgar Wind, „Krytyka znawstwa”, przekł. Maria Klukowa, w: Pojęcia, problemy, metody wspótczesnej nauki o sztuce, red. Jan Białostocki, Warszawa 1976, s. 170-192. Podobną postawę metodologiczną przyjąłem w odniesieniu do anonimowego motetu Exsultate, gaudete laeti omnes z wawelskiego rękopisu Kk I.15. Por. Tomasz Jasiński, „Anonimowy motet Exsultate gaudete laeti omnes kompozycją Gorczyckiego?”, Annales Univeritatis Mariae Curie-Sktodowska, Sectio L, Artes 10 (2013) nr 1, s. 77-111. 
Przykł. 8. Psalm Dawida, t. 50

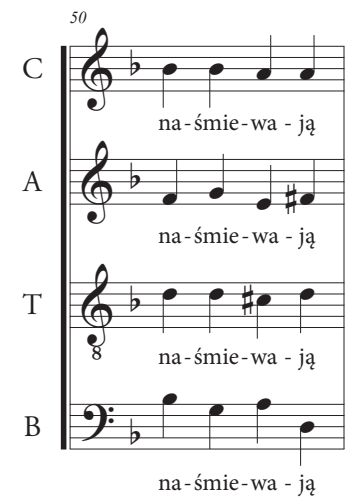

Takie same upostaciowania dźwiękowo-fakturalne lub bardzo do nich podobne kilkakrotnie spotykamy u Gomółki:

Przykł. 9a. Mikołaj Gomółka, Psalm LV, t. 2-3

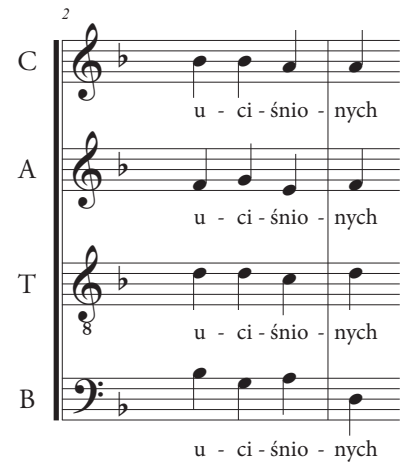

Przykł. 9b. Mikołaj Gomółka,

Psalm VI, t. I2
Przykł. 9c. Mikołaj Gomółka,

Psalm XXXII, t. 7
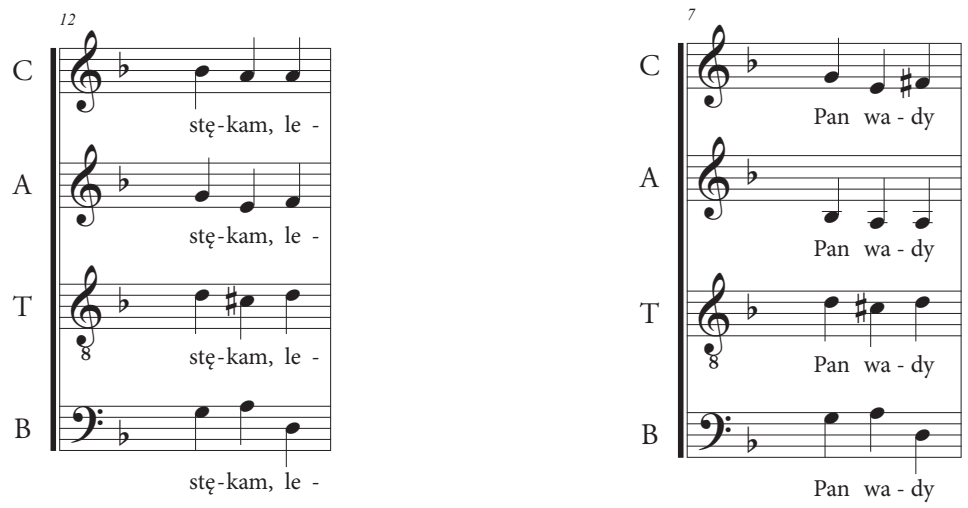
Analogiczne zbieżności takich „przypadkowych” kształtów, tym razem na gruncie melodyki, dostrzegamy w strukturze rytmiczno-melodycznej, która rozwija się na tle dłuższych wartości pozostałych głosów (identyczności kształtów zaznaczono klamrami). W Psalmie Dawida, po cezurze, pojawia się fragment, w którym tenor rozwija linię melodyczną: $e^{\mathrm{I}}$ (punktowana półnuta) $-d^{\mathrm{I}}$ (ćwierćnuta) $-e^{\mathrm{I}}$ (ćwierćnuta) $-f^{\mathrm{I}}$ (ćwierćnuta) $-g^{\mathrm{I}}$ (półnuta):

Przykł. Io. Psalm Dawida, t. 30-32

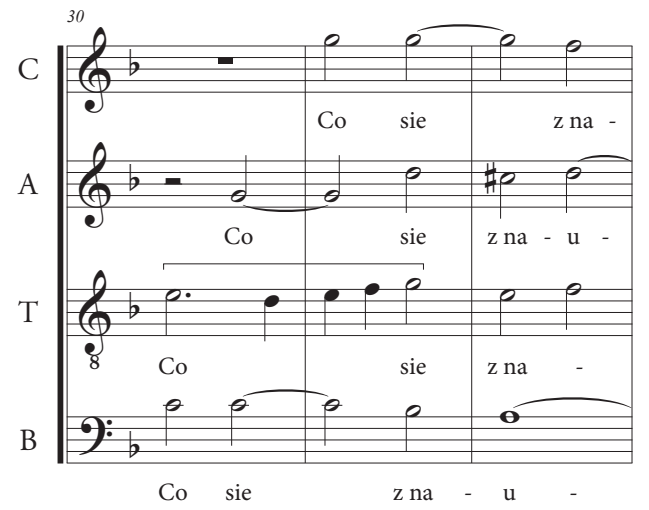

U Gomółki znajdujemy trzykrotnie bliźniacze kształty. Pojawiają się one na początku utworu, zawsze - tak jak w Psalmie Dawida - rozpoczynają się od tercji aktualnie rozbrzmiewającego trójdźwięku, notabene w jednym miejscu, podobnie jak w Psalmie, także w powiązaniu ze słowem „Co”:

Przykł. Iıa. Mikołaj Gomółka, Psalm CIIII, t. I-2

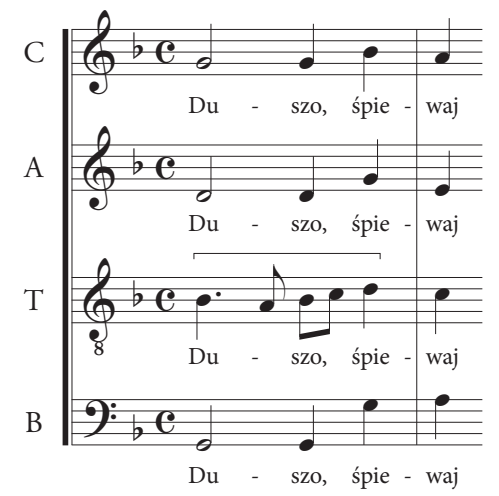


Przykł. iıb. Mikołaj Gomółka, Psalm LVII, t. I-3

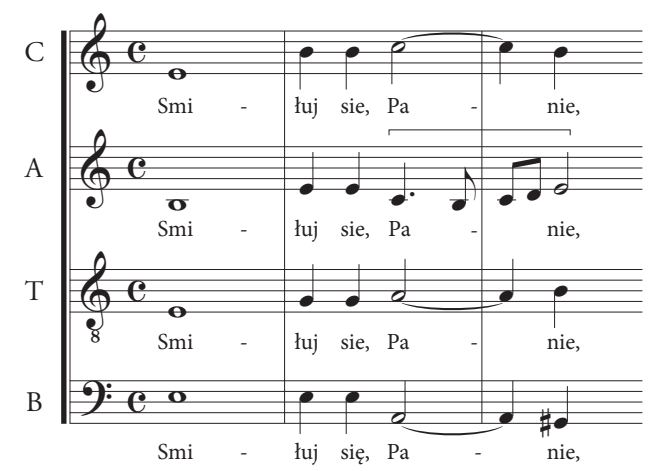

Przykł. IIc. Mikołaj Gomółka, Psalm II, t. I-2

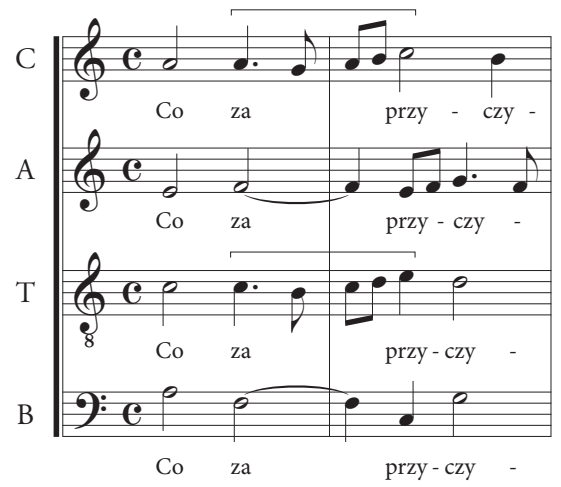

Podobnego „ruchu ręką” możemy dopatrzeć się w niektórych relacjach melodyczno-kontrapunktycznych między dwoma głosami. Oto kolejny fragment Psalmu Dawida, tym razem z wyselekcjonowaną parą głosów:

Przykł. I2. Psalm Dawida, Tenor i Bassus, t. 8I-83

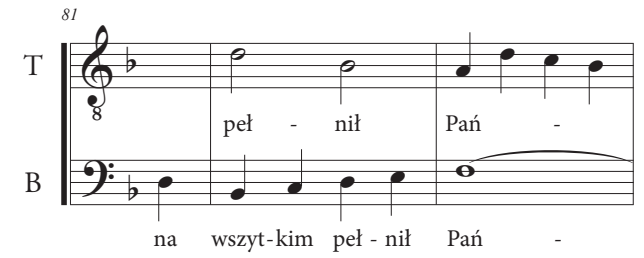

Widzimy tu wstępujący pochód basu ruchem łącznym $(B-c-d-e-f)$, któremu następnie odpowiada opadająca sekundami linia tenoru $\left(d^{\mathrm{I}}-c^{\mathrm{I}}-b\right)$. Podobne „gesty” kontrapunktyczne spotykamy u Gomółki: 
Przykł. ıза. Mikołaj Gomółka, Psalm VI, Cantus i Bassus, t. I9-2I

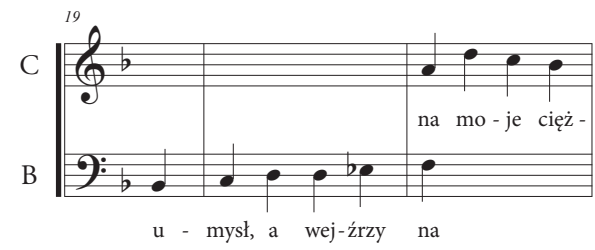

Przykł. ıзb. Mikołaj Gomółka, Psalm LV, Tenor i Bassus, t. 7-ıо

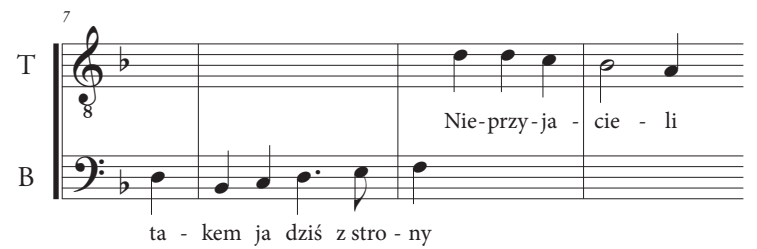

Zbieżności tych nie można bagatelizować. Mogą one bowiem ilustrować sytuację, w której twórca sięga w różnych swoich dziełach, nawet wyraźnie od siebie odmiennych, po te same lub bardzo podobne do siebie struktury, czyniąc to machinalnie, do pewnego stopnia nieświadomie. Sądzę, że właśnie w owych ewidentnych podobieństwach rozmaitych struktur epizodycznych kryje się jeden z najpoważniejszych argumentów dla hipotezy, iż Psalm mógł wyjść spod ręki Gomółki.

I jeszcze jedno rzucające się w oczy pokrewieństwo między Melodiami a Psalmem, choć nieco ambiwalentne. Uprzednio zwróciliśmy uwagę na pewne różnice między kadencjami u Gomółki a tymi, które występują w Psalmie, ale teraz jednak dodajmy, że i w tym składniku dzieła - skądinąd z swojej istoty najbardziej podatnym na oddziaływanie powszechnych konwencji, najmniej zindywidualizowanym - wielokrotnie zachodzą uderzające zbieżności. Najpierw przypomnijmy końcowy odcinek kadencyjny z Psalmu Dawida:

Przykł. I4. Psalm Dawida, t. 93-96

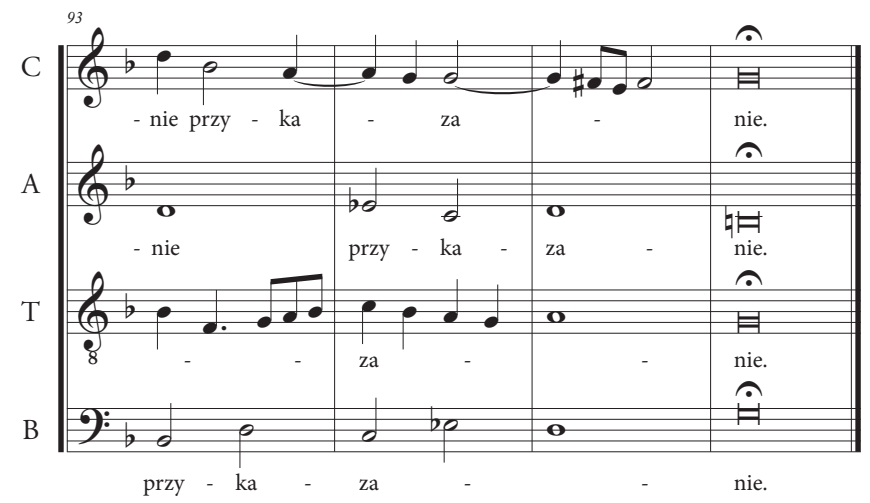


Bardzo podobne, a nawet bliźniacze kształty odnajdujemy u Gomółki, m.in.: zbieżności w pochodach melodycznych basu, dysonans wynikający z nieprzygotowanego opóźnienia seksty na kwintę (współbrzmienie: $e s-a-c^{\mathrm{I}}-g^{\mathrm{I}}$ ), podobne układy fakturalne, często niemal takie samo prowadzenie głosów:

Przykł. I5a. Mikołaj Gomółka, Psalm XXVIII, t. II-I3

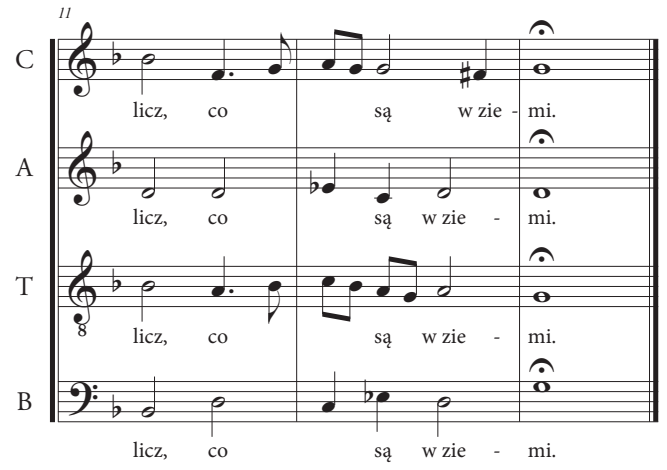

Przykł. isb. Mikołaj Gomółka, Psalm LXIIII, t. 6-7

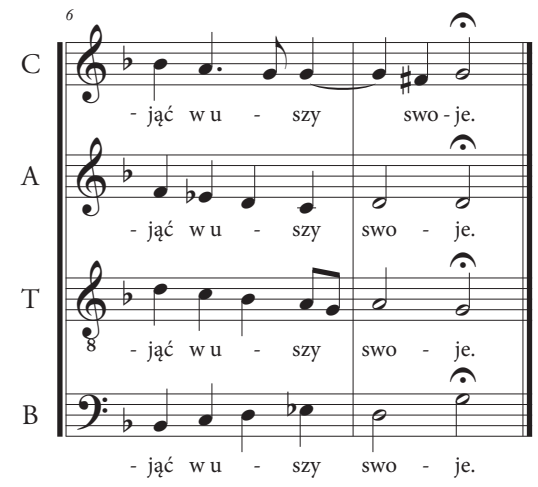

Przykł. I5c. Mikołaj Gomółka, Psalm CXXXIX, t. I3-I4

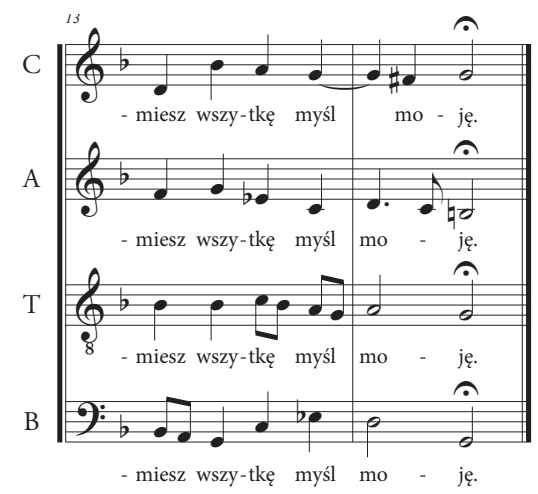


Przykł. Isd. Mikołaj Gomółka, Psalm XLVI, t. 9-II

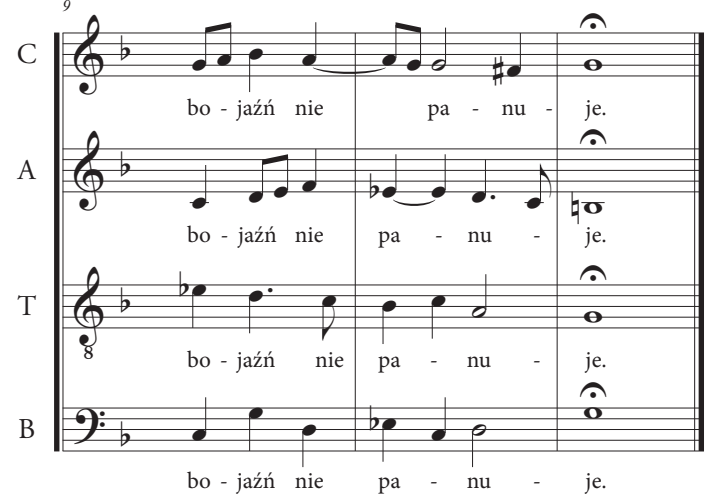

Przykł. Ise. Mikołaj Gomółka, Psalm LXXVII, t. II-I3

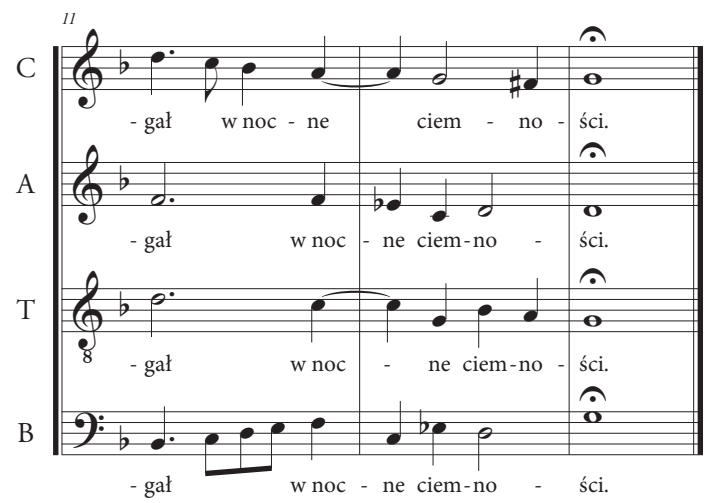

Przykł. Isf. Mikołaj Gomółka, Psalm LXXX, t. I3-I5

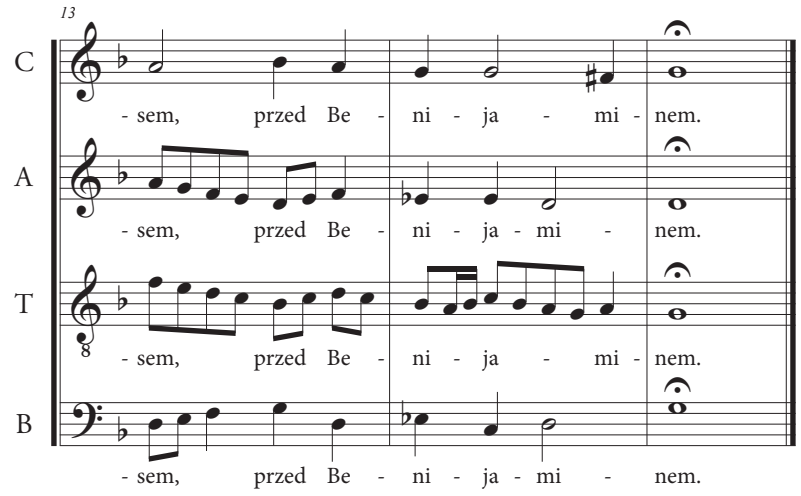


Przytoczone fragmenty pokazują, że odcinek zamykający Psalm Dawida mieści się w formułach kadencyjnych Gomółki, więcej nawet - najściślej z nimi koresponduje. Zwróćmy równocześnie uwagę na fakt, że pokrewieństwa w zakresie kadencji i wcześniej pokazane zbieżności zachodzą niemal bez wyjątku w psalmach in $g$ (tonacja dorycka transponowana do $g$ ), gdzie uwarunkowania modalne mogą podsuwać kompozytorowi takie same lub bardzo zbliżone do siebie układy dźwięków.

Trzeba też powiedzieć o kilku podobieństwach natury strukturalnej. Nie dotyczą one konkretnych kształtów muzycznych, które można by ze sobą porównywać i dopatrywać się w nich tej samej „ręki”, lecz polegają na analogiach i pokrewieństwach, wyznaczających określone ramy konstrukcji polifonicznej.

Warto zauważyć, że wiele psalmów Gomółki rozpoczyna się, podobnie jak w Psalmie Dawida, repetycją pierwszego odcinka (z uwagi na odmienność form nie tak rozbudowanego jak w Psalmie). W większości tych psalmów (są to psalmy: XIII, XIIII, XVII, XXIII, XXIX, XXXVII, LIII, LV, LXII, XCI, CIII, CIX, CXXII, CXVII, CXL) drugi odcinek kompozycji, tj. następujący bezpośrednio po znaku repetycji, rozpoczyna się od tego samego ugrupowania rytmicznego, który inicjuje odcinek pierwszy (co w pierwszym rzędzie wynika z prozodii wiersza). Identyczną sytuację mamy w Psalmie.

Druga kwestia wiąże się z polem dźwiękowym struktury wielogłosowej i zakresami poszczególnych głosów. Psalm Dawida utrzymany jest w modus $g$-doryckim. Wypełnia pole dźwiękowe obejmujące trzy oktawy: $G-g^{2}$, zarówno w odniesieniu do całej kompozycji, jak i do prima pars oraz secunda pars rozpatrywanych osobno. Cantus mieści się w zakresie: $d^{\mathrm{I}}-g^{2}$; Altus: $g-d^{2}$; Tenor: $d-a^{\mathrm{I}}$; Bassus: $G-d^{\mathrm{I}}$. Są przy tym nieznaczne różnice między obiema częściami motetu. W prima pars (chiavetta: G2-CI-C3-F3) Cantus ma nieco węższy zakres $\left(f i s^{\mathrm{I}}-g^{2}\right)$, Altus także $\left(c^{\mathrm{I}}-d^{2}\right)$, podobnie Tenor $\left(g-a^{\mathrm{I}}\right)$, Bassus zaś odpowiada ogólnej normie kompozycji $\left(G-d^{\mathrm{I}}\right)$. W secunda pars (chiavetta: $\mathrm{G}_{2}-\mathrm{C}_{2}-\mathrm{C}_{3}-\mathrm{F}_{3}$ ) zakresy głosów są rozleglejsze (Cantus: $d^{\mathrm{I}}-g^{2}$; Altus: $g-c^{2}$; Tenor: $\left.d-f^{1}\right)$, oprócz basu, który mieści się w takim samym ambitus jak w prima pars $\left(G-d^{\mathrm{I}}\right)$.

Ten stan rzeczy zestawmy z psalmami Gomółki, które utrzymane są w modus g-doryckim (finalis $g$, jeden bemol przy kluczu) i mają chiavetty: $\mathrm{G}_{2}-\mathrm{CI}_{-}-\mathrm{C}_{3}-\mathrm{F}_{3}$ oraz $\mathrm{G}_{2}-\mathrm{C}_{2}-\mathrm{C}_{3}-\mathrm{F}_{3}$.

W pierwszej grupie psalmów, odpowiadającej zestawem kluczy pierwszej części Psalmu Dawida, obejmującej dwa utwory (psalmy: XVI, CXXIII), pole dźwiękowe jest identyczne jak w Psalmie $\left(G-g^{2}\right)$; taki sam jak w Psalmie jest również ambitus basu $\left(G-d^{\mathrm{I}}\right)$. Sopran i tenor, w obu psalmach mające identyczny ambitus (Cantus: $g^{\mathrm{I}}-g^{2}$; Tenor: $\left.g-g^{I}\right)$, minimalnie różnią się od zakresów swoich odpowiedników w Psalmie. Odmiennie w obu psalmach przedstawiają się natomiast zakresy altu: $c^{\mathrm{I}}-d^{2}$ (psalm XVI) i $f^{\mathrm{I}}-d^{2}$ (psalm CXXIII); jednocześnie trzeba odnotować, że ambitus altu w psalmie XVI pokrywa się z zakresem altu w Psalmie Dawida. 
W drugiej grupie psalmów, z zestawem kluczy odpowiadającym drugiej części Psalmu, liczącej dużo więcej, bo dziesięć utworów (psalmy: VI, VII, XXVIII, XLII, XLVI, L, LXXVII, LXXX, CXLII[a], CXLII[b]), sytuacja jest bardziej zróżnicowana.

Najczęściej wypełniane jest pole dźwiękowe: $B-f^{2}$ (psalmy: VI, XLVI, LXXVII, LXXX), do czego dochodzą pokrewne pod względem rozpiętości pola dźwiękowe: $B-g^{2}$ (psalm XXVIII), $A-f^{2}(\mathrm{~L})$, oraz bardziej rozległe: $F-f^{2}$ (psalm VII), $G-g^{2}$ (psalm XLII). Dwukrotnie mamy wyraźnie węższe pole: $c-d^{2}$ (psalmy: CXLII[a], CXLII[b]). Pole dźwiękowe wskazanych psalmów mieści się zatem w większości między dwiema oktawami i kwintą a trzema oktawami. Górną granicę wyznacza dźwięk $f^{2}$ lub $g^{2}$, dolna zaś mieści się między dźwiękami $F$ a $B$.

Ambitus sopranu oscyluje wokół oktawy. Mamy tu następujące zakresy: $f^{1}-f^{2}$ (psalmy: VI, XLVI, L), fis ${ }^{\mathrm{I}}-f^{2}$ (psalmy: LXXVII, LXXX), $f^{\mathrm{I}}-g^{2}$ (psalmy: XXVIII, XLII), $e s^{I}-f^{2}$ (psalm VII), do czego dochodzi jeden rozleglejszy ambitus: $d^{1}-g^{2}$ (psalmy: CXLII[a], CXLII[b]). Górną granicę sopranu wyznacza dźwięk $f^{2} \operatorname{lub} g^{2}$, dolną najczęściej $f^{\mathrm{I}} / f_{i s}^{\mathrm{I}}$.

Ambitus altu jest najbardziej labilny spośród wszystkich głosów. Mamy tu zakresy przekraczające oktawę: $g-c^{2}$ (psalmy: VII, LXXVII), $g-b^{\mathrm{I}}$ (psalm LXXX), $a-b^{\mathrm{I}}$ (psalmy: VI, CXLII[a], CXLII[b]), $h-c^{2}$ (psalm L), wypełniające oktawę: $c^{\mathrm{I}}-c^{2}$ (psalm XXVIII), $b-b^{\mathrm{I}}$ (psalm XLVI); w jednym wypadku ambitus wypełnia septymę $d^{\mathrm{I}}-c^{2}$ (psalm XLII). Za górną granicę zakresu altu można przyjąć dźwięk $b^{\mathrm{r}}$ $\operatorname{lub} c^{2}$, za dolną - dźwięki mieszczące się między $g$ a $c^{\mathrm{I}}$.

Najbardziej stabilny jest ambitus tenoru. W aż sześciu psalmach wypełnia on oktawę $g-g^{I}$ (psalmy: VI, VII, XXVIII, XLVI, L, LXXVII), w jednym wypadku oktawę $f-f^{I}$ (psalm CXLII[a]), a w dwóch innych nieznacznie ją przekracza, osiągając dystans nony $f-g^{I}$ (psalmy: LXXX, CXLII[b]) i decymy $f-a^{I}$ (psalm XLII). Górna granica tego głosu to dźwięk $g^{\mathrm{I}}$ lub okazjonalnie $a^{\mathrm{I}}$, dolna zaś to dźwięk $g$ $\operatorname{lub} f$.

W basie pierwszoplanowe miejsce zajmuje ambitus $B-d^{\mathrm{I}}$ (psalmy: VI, XXVIII, LXXVII, LXXX); obok niego mamy zakresy rozleglejsze: $F-c^{\mathrm{I}}$ (psalm VII), $G-d^{\mathrm{I}}$ (psalm XLII), $A-d^{\mathrm{I}}$ (psalm L), i nieco węższe: $c-d^{\mathrm{I}}$ (psalmy: CXLII[a], CXLII[b]), $B-b$ (psalm XLVI). Najbardziej czytelna jest w tym wypadku górna granica głosu, przypadająca w większości na dźwięk $d^{\mathrm{I}}$. Granica dolna najczęściej wiąże się z dźwiękiem $B$, choć opada niekiedy do $A, G$ i $F$.

Jak na tym tle przedstawia się Psalm Dawida? Trzeba najpierw ogólnie stwierdzić, że pole dźwiękowe całej struktury brzmieniowej oraz zakresy poszczególnych głosów w Psalmie mieszczą się w obrazie struktury głosowej psalmów Gomółki wyznaczonych przez chiavetty: $\mathrm{G}_{2}-\mathrm{C}_{1}-\mathrm{C}_{3}-\mathrm{F}_{3}$ i $\mathrm{G}_{2}-\mathrm{C}_{2}-\mathrm{C}_{3}-\mathrm{F}_{3}$. Oczywiście, jest u Gomółki pod tym względem różnorodność, a nadto opisane relacje w jego psalmach odpowiadają - z istoty rzeczy - ogólnym normom modalnym obowiązującym 
w polifonii XVI stulecia ${ }^{20}$. Nie można więc przeprowadzać naszej konfrontacji zbyt rygorystycznie. Warto równocześnie zauważyć, że maksymalne pole dźwiękowe oraz nieco większe zakresy poszczególnych głosów w Psalmie aniżeli „uśrednione” zakresy w utworach Gomółki wynikają, po pierwsze, z większych rozmiarów motetu, zdecydowanie przewyższających pieśniowe Melodie, po drugie - z bardziej zaawansowanego linearyzmu, będącego pochodną zastosowania techniki przeimitowania.

Gdy rozpatrujemy psalmy Gomółki utrzymane w modus g-doryckim, warto zwrócić uwagę na ich plany tonalne. W utworach tych kadencje budowane są na stopniach: pierwszym $(g)$, piątym $(d)$ i trzecim $(b)^{21}$, bywa też niekiedy, że i na czwartym $(c)^{22}$. Dokładnie w tym kręgu mieści się plan tonalny Psalmu Dawida (prima pars, t. I-I9: $g-d-g$; t. 20-34: $c-d-c-d$; t. 35-55: $g-d-g-c-d-b-g-d-g-c-d-b-g$; secunda pars, t. 56-96: $g-b-g$ ), przy tym - tak samo jak u Gomółki - kadencje na czwartym stopniu stanowią zjawisko rzadsze, raczej epizodyczne.

Wszystkie wskazane pokrewieństwa i analogie między Psalmem Dawida a Melodiami na Psalterz polski winny być traktowane łącznie, jako zbiorczy syndrom odsłaniający parcjalną więź Psalmu z poetyką Gomółki. Cóż jednak ze wszystkimi zjawiskami w Psalmie, które wyraźnie rozmijają się ze stylistyką Melodii? Czy wykluczają one sugerowaną przeze mnie atrybucję?

Zamiast odpowiedzi proponuję rozważenie sytuacji czysto teoretycznej. Wyobraźmy sobie, że znamy tylko trzy psalmy Mikołaja Gomółki - Kleszczmy rękoma wszyscy zgodliwie, Nieście chwate, mocarze, Panu mocniejszemu i Radujcie się Bogu nawyższemu. I oto znajdujemy w jakimś dawnym rękopisie jego psalm Siedzac po niskich brzegach babilońskiej wody - przekazany anonimowo. Czy ktoś wtedy odważyłby się owo „zuchwalstwo harmoniczne” ${ }^{23}$ przypisać Gomółce?

20 Na temat szesnastowiecznych norm modalnych, w tym również tych, które dotyczą zakresów poszczególnych głosów struktury polifonicznej, zob.: Zofia Dobrzańska-Fabiańska, Spór o role „modus” " „tonalité" w sztuce kompozycji XVI i początku XVII wieku, Kraków 2013, s. 31-47, passim.

21 Zob.: Mirosław Perz, Melodie na Psatterz polski Mikotaja Gomótki. Interpretacje i komentarze, Kraków 1988, s. 68, 114, 209, passim.

22 Zob. ibid., s. 159, passim.

23 Określenie Aleksandra Polińskiego. Cyt za: ibid., s. 197. 


\section{BIBLIOGRAFIA}

Dobrzańska-Fabiańska, Zofia. Spór o role 'modus' i 'tonalité' $w$ sztuce kompozycji XVI i początku XVII wieku. Kraków: Musica Iagellonica, 2013.

Gomółka, Mikołaj. Melodie na Psatterz polski. Facsimile pierwodruku, wyd. Mirosław Perz. Kraków: PWM, 198I.

Gomółka, Mikołaj. Melodie na Psatterz polski przektadania Jana Kochanowskiego. Transkrypcja, wyd. Mirosław Perz, opr. krytyczne tekstu Jerzy Woronczak. Kraków PWM, 1983.

Jasiński, Tomasz. „Anonimowy motet Exsultate gaudete laeti omnes kompozycją Gorczyckiego?”. Annales Univeritatis Mariae Curie-Sktodowska, Sectio L, Artes Io, nr I (2013): 77-III.

Jasiński, Tomasz. „Rekonstrukcja warstwy słownej pieśni Stuchaj, co żywo zapisanej w tabulaturze organowej z Kroż”. Muzyka 66, nr I (202I): I69-I79.

Liber Organistarum Collegii Crosensis Societatis Jesu, wyd. Laima Budzinauskienè, Rasa Murauskaitė. Warszawa: Wydawnictwo Naukowe Sub Lupa, 2017 (= Fontes Musicae in Polonia, Seria B, 2).

Ostaszewska, Ewa. „Kochanowski Jan”. W: Encyklopedia Muzyczna PWM. Część biograficzna, red. Elżbieta Dziębowska. T. 5, II4-II5. Kraków: PWM, 1997.

Perz, Mirosław. Melodie na Psatterz polski Mikotaja Gomótki. Interpretacje i komentarze. Kraków: PWM, 1988.

Perz, Mirosław. Mikotaj Gomótka. Monografia. Kraków: PWM, I98I.

Przybyszewska-Jarmińska, Barbara. Barok, część pierwsza: 1595-1696. Warszawa: Sutkowski Edition, 2006 (= Historia muzyki polskiej 3).

Wind, Edgar. „Krytyka znawstwa”, przekł. Maria Klukowa. W: Pojęcia, problemy, metody wspótczesnej nauki o sztuce, red. Jan Białostocki, I70-192. Warszawa: Wydawnictwo Naukowe PWN, 1976.

\section{A TEXTLESS ANONYMOUS SETTING OF A PSALM OF DAVID IN THE KRAŽIAI ORGAN TABLATURE. TEXT RECONSTRUCTION AND ATTEMPTED ATTRIBUTION}

This article concerns an anonymous Psalm of David entered in a seventeenth-century organ tablature from Kražiai (Lithuania). It is a four-part composition a voce piena, quite long ( 96 bars), in two sections, written in vocal notation in the form of a score, but without a verbal text.

In the first section of the article, the author demonstrates that this is a setting of the first Psalm of David in a poetic rendition by Jan Kochanowski ('Szczęśliwy, który nie był miedzy złemi w radzie' / 'Blessed is the Man Who Walks Not in the Counsel of the Wicked'), based on the melody of the same psalm found in Petrus Artomius' Cantional of I640. In the transcription presented here, no real difficulty was encountered with underlaying Kochanowski's text. Only in some sections (e.g. bars 57-85) was a degree of intuition required. The Psalm of David stands out in several respects: a motet with vernacular text (a generic novelty in early Polish music), it is a previously unknown motet setting of verse by Kochanowski, distinguished by impeccable counterpoint, excellent voice-leading, a full sound, clear tonal relations, motivic 
unity and rhythmic-textural diversity, as well as expressive coherence in the correlation of words and music.

In the second part of the article, the author hypothesises that the Psalm of David may have been composed by Mikołaj Gomółka (I535-after I59I) and presents a comparative analysis between this work and Gomółka’s Melodie na Psatterz polski (Melodies for the Polish Psalter). The author lists numerous differences between the two, but also points to various affinities and similarities in the melody, rhythm, harmony and other elements which seem to support the thesis that this work was written by Gomółka. There is no unequivocal conclusion to this research study; instead, it leaves the reader with an intriguing question.

Translated by Tomasz Zymer

Słowa kluczowe / keywords: Tabulatora organowa z Kroż / Kražiai organ tablature, Psalm Dawida / Psalm of David, rekonstrukcja tekstu / text reconstruction, Jan Kochanowski, porównawcza analiza muzyczna / comparative music analysis, Mikołaj Gomółka

Dr hab. Tomasz Jasiński, prof. UMCS, muzykolog, pracownik naukowo-dydaktyczny w Instytucie Muzyki Wydziału Artystycznego Uniwersytetu Marii Curie-Skłodowskiej w Lublinie. W swoich badaniach naukowych koncentruje się na muzyce dawnej.

tomaszjasinski@op.pl

\title{
Nowość wydawnicza Instytutu Sztuki PAN
}

\author{
Pawel Gancarczyk \\ Petrus Wilhelmi de Grudencz i muzyka \\ Europy Środkowej XV wieku
}

ramówienia:wydawnictwo@ispan.pl 